\section{Grafting Melons Increases Yield, Extends the Harvest Season, and Prevents Sudden Wilt in New England}

\author{
Janel L. Ohletz ${ }^{1}$ and J. Brent Loy ${ }^{1}$
}

ADDITIONAL INDEX WORDs. Cucumis melo, interspecific hybrid rootstocks, northeastern United States, soluble solids content

SUMMARY. Melons (Cucumis melo var. reticulatis) are potentially a high value crop for New England, but production is limited by cool spring temperatures and sudden wilt. The sudden wilt syndrome in melon, attributed to both biotic and abiotic factors, is characterized by rapid wilting of vines either just preceding or during the harvest season, reducing melon quality and shortening the harvest period. We investigated the effects of grafting melons to rootstocks of interspecific hybrid squash (Cucurbita maxima $\times$ C. moschata), which have exhibited tolerance to soilborne diseases and cooler soil temperatures. In 2015, we compared the performance of 'Halona' melon grafted to two rootstocks, 'Carnivor' and 'NH1320', to that of nongrafted (NG) plants at two New Hampshire Agriculture Experiment Research Farms, Woodman (WRF) and Kingman (KRF). Pistillate flowering and melon harvests were 3 to 9 days earlier in NG than grafted (GR) plants. By harvest period, GR plant growth exceeded that of NG plants, and GR plants did not display wilting symptoms observed in NG plants. Total marketable yields were $57 \%$ and $90 \%$ higher for GR/'Carnivor' (47.8 and $45.0 \mathrm{Mg} \cdot \mathrm{ha}^{-1}$ ) and $44 \%$ and $89 \%$ higher for GR/ 'NH1320' (43.9 and $\left.44.9 \mathrm{Mg} \cdot \mathrm{ha}^{-1}\right)$ compared with the NG treatment $(30.5$ and $23.7 \mathrm{Mg} \cdot \mathrm{ha}^{-1}$ ) at WRF and KRF, respectively. There were no differences in fruit numbers per plot between treatments, but mean fruit weight was between $33 \%$ and $71 \%$ larger in GR than NG treatments. In 2016, GR ('NH1320' rootstock) and NG 'Halona' were compared at three transplantation dates, 12 and 21 May and 1 June, and with two irrigation frequencies, drip irrigation every 2 days (2-d Irr) or every 4 days (4-d Irr). NG plants exhibited symptoms of sudden wilt in early August compared with no symptoms on GR plants. Harvests of NG melons were 3 to 8 days earlier than GR plants for all three planting dates. The increase in yields of GR plants compared with NG plants for the 12 and 21 May and 1 June planting dates were, respectively, $131 \%, 123 \%$, and $149 \%$ greater with the 2 -day Irr, and $93 \%$, $100 \%$, and $78 \%$ greater with 4 -d Irr. Irrigation frequency did not significantly affect fruit size or soluble solids content (SSC), whereas grafting increased both fruit number and fruit size but did not significantly affect SSC at all three planting dates.

Received for publication 8 June 2020. Accepted for publication 12 Oct. 2020

Published online 3 December 2020

${ }^{1}$ Department of Agriculture, Nutrition and Food Systems, University of New Hampshire, Durham, NH 03824

Partial funding was provided by the New Hampshire Agricultural Experiment Station. This is Scientific Contribution Number 2867. This work was supported by the U.S. Department of Agriculture, National Institute of Food and Agriculture (Hatch Projects NH00548 and NH00609).

We thank John McLean, Evan Ford, David Goudreault, and Luke Hydock for technical assistance; AgriFabrics, LLC, Alpharetta, GA, for the donation of Agribon floating rowcover.

This is dedicated to the late James Brent Loy, PhD, colleague, mentor, and friend. J.B.L. passed away on 24 July 2020

J.L.O. is the corresponding author. E-mail: jlmart17@ ncsu.edu.

This is an open access article distributed under the CC BY-NC-ND license (https://creativecommons.org/ licenses/by-nc-nd/4.0/).

https://doi.org/10.21273/HORTTECH04669-20
$\mathrm{M}$ elons (Cucumis melo var. reticulatis), also known as cantaloupe, were considered to be marginal crop for most of New England before 1980 because of cold air and soil temperatures during the spring, a short growing season, and lack of cultivars adapted to early- season culture. However, beginning in the mid-1970s, improved cultural techniques using different plastic mulches and rowcovers provided technologies for extending the growing season and increasing melon yields in northern latitudes (Hemphill and Mansour, 1986; Loy, 1991; Loy and Wells, 1975, 1982; Wells and Loy, 1985; Wells et al., 1977). In addition, progress in plant breeding between the mid-1980s and 2010 resulted in the introduction of several new cultivars with improved eating quality, disease resistance, earlier maturity, and adaptation to the northeastern United States (Loy, 2013). Moreover, as a result of climate change during the past 35 years, the frost-free growing season throughout much of New England has been extended by as much as 2 weeks (Kunkel, 2016). Nonetheless, despite the high value and consumer demand for locally grown melons, reported melon production in New England amounts to less than 250 acres [U.S. Department of Agriculture (USDA), 2018].

The lack of more rapid expansion of melon production in New England can in part be attributed to variable spring weather contributing to periods of cool air and soil temperatures that are not conducive to early melon growth (Jenni et al., 1996; Korkmaz and Dufault, 2001), often resulting in plant loss due to chilling injury (CI) (Loy and Wells, 1983; Waterer, 1993). Although high-tunnel production of warm-season crops has increased in the northeastern United States, Vescera and Brown (2016) suggested that high-tunnel production of melons intended for New England markets was not economically feasible. Another major factor

\begin{tabular}{llll}
\hline $\begin{array}{l}\text { Units } \\
\begin{array}{l}\text { To convert U.S. to SI, } \\
\text { multiply by }\end{array}\end{array}$ & U.S. unit & SI unit & $\begin{array}{l}\text { To convert SI to U.S., } \\
\text { multiply by }\end{array}$ \\
\hline 0.3048 & $\mathrm{ft}$ & $\mathrm{m}$ & 3.2808 \\
3.7854 & $\mathrm{gal}$ & $\mathrm{L}$ & 0.2642 \\
2.54 & inch $(\mathrm{es})$ & $\mathrm{cm}$ & 0.3937 \\
25.4 & inch $(\mathrm{es})$ & $\mathrm{mm}$ & 0.0394 \\
0.4536 & $\mathrm{lb}$ & $\mathrm{kg}$ & 2.2046 \\
1.1209 & $\mathrm{lb} / \mathrm{acre}$ & $\mathrm{kg} \cdot \mathrm{ha}$ & 0.8922 \\
0.0254 & $\mathrm{mil}(\mathrm{s})$ & $\mathrm{mm}$ & 39.3701 \\
28.3495 & $\mathrm{oz}$ & $\mathrm{g}$ & 0.0353 \\
33.9057 & $\mathrm{oz} / \mathrm{yard}{ }^{2}$ & $\mathrm{~g} \cdot \mathrm{m}^{-2}$ & 0.0295 \\
1 & $\mathrm{ppm}$ & $\mathrm{mg} \cdot \mathrm{L}^{-1}$ & 1 \\
2.2417 & ton $(\mathrm{s}) / \mathrm{acre}$ & $\mathrm{Mg} \cdot \mathrm{ha}^{-1}$ & 0.4461 \\
$\left({ }^{\circ} \mathrm{F}-32\right) \div 1.8$ & ${ }^{\circ} \mathrm{F}$ & ${ }^{\circ} \mathrm{C}$ & $\left({ }^{\circ} \mathrm{C} \times 1.8\right)+32$
\end{tabular}

Hortlechnology $\cdot$ February $202131(1)$ 
limiting production of melons in New England and throughout the northeastern United States for several decades is a syndrome termed "sudden wilt" (Zitter, 1995). Also known as vine decline or vine collapse, sudden wilt is characterized by rapid wilting when the plant has a full fruit load. Sudden wilt appears to be especially problematic for early-maturing cultivars characterized by limited leaf canopy development in relation to fruit load (J.B. Loy, unpublished observations). Soilborne pathogens are usually invoked as the main cause of sudden wilt, reducing the capacity of the root system to uptake water and nutrients (Martyn, 2007). However, in much of the northeastern United States, it has not been possible to associate a particular soilborne pathogen with sudden wilt (Zitter, 1995), and environmental stresses such as cold soils, excessively hot weather, and low light intensity may exacerbate wilting (Martyn, 2007; Wien and Zitter, 2006).

Vegetative grafting is a cultural technique widely adopted throughout much of Asia for more than half a century to alleviate problems with soilborne diseases and environmental constraints for growth of melon, cucumber (Cucumis sativus), and watermelon (Citrullus lanatus) (Gaion et al., 2018; Lee, 1994; Lee and Oda, 2003; Rouphael et al., 2018; Sakata et al., 2007; Wang et al., 2019), although primarily for plants grown in greenhouses and other protected structures. The most common rootstocks used in melon grafting are interspecific hybrid squash [Cucurbita maxima $\times C$. moschata (King et al., 2010)]. Because of the vigorous root systems and general disease resistance of these rootstocks to soilborne diseases (Cohen et al., 2002; Davis et al., 2008; Lee, 1994; Lee et al., 2009), melon grafting may offer a solution for overcoming problems with sudden wilt in field-grown melons. In addition, interspecific hybrid rootstocks can tolerate abiotic stresses such as cold soil temperatures (Jenni et al., 1996; Korkmaz and Dufault, 2001) and moisture stress (Kumar et al., 2017; Lee and Oda, 2003; Proietti et al., 2008; Schwarz et al., 2010 ) better than melon. However, grafting to certain rootstocks has been linked to potential drawbacks related to flavor compounds, texture, and fruit size (Rouphael et al., 2010).

Melon grafting is a relatively new but expanding field of study in the United States (Davis et al., 2008; Kubota et al., 2008); however, data on the field performance of melon in North America are limited, and such information is lacking for the northeastern United States. Recurring problems with sudden wilt in our melon research plots, together with development of potential rootstocks from breeding research at the New Hampshire Agricultural Experiment Station on interspecific hybrid squash (Loy, 2015; Uretsky, 2012), were the impetus for our study in grafting melons to squash rootstocks. The objectives of this research were to l) evaluate melon grafting onto interspecific hybrid squash rootstocks as a technique for alleviating sudden wilt in fieldgrown melons, 2) compare yield and fruit quality in field-grown GR and NG melons under two irrigation regimes, and 3 ) determine whether grafting to interspecific rootstocks can enable greater season extension.

\section{Materials and methods}

Plant material and growing CONDITIONS, 2015. GR and NG plants of 'Halona' melon (Hollar Seeds, Rocky Ford, CO) were compared in two separate research plots, one in Durham, NH (WRF) and the other in Madbury, NH (KRF) (both lat. $\left.43^{\circ} \mathrm{N}\right)$. Melons have not been grown for several years at the WRF site, whereas melons grown during several seasons over the past 20 years at the KRF site exhibited symptoms of sudden wilt. The study was of ' $\mathrm{Hal}$ ona' melon grafted to two interspecific hybrid squash rootstocks as the treatment and NG melon as the control. The rootstocks were 'NH1320', an interspecific hybrid developed at the University of $\mathrm{New}$ Hampshire (UNH) by J.B. Loy and 'Carnivor', a widely used commercial rootstock cultivar, seeds of which were donated by Syngenta Seeds (Woodstock, CA). Field performance of NG and GR were compared.

The soil type is Charlton fine sandy loams (mixed mesic, Entic Lithic Haplorthods) at both locations. Fields were planted to winter ryegrass
(Secale cereale) during the previous fall. The winter ryegrass was ploughed and harrowed 2 to 3 weeks before bed preparation. Fertilizer was broadcast-applied at a rate of $90 \mathrm{lb} /$ acre nitrogen $(\mathrm{N})$ and $75 \mathrm{lb} / \mathrm{acre}$ potassium $(\mathrm{K})$, before bed formation ( $2 \mathrm{ft}$ wide $\times 6$ inches high). According to soil test results, phosphorus (P) levels were high and no application was needed. In 2015, biodegradable mulch $[0.6$ mil thick $\times 135 \mathrm{~cm}$ wide (BioTelo; Filnova, Segrate, Italy)] and drip tape [1-ft emitter spacing, 1.0 L.h ${ }^{-1}$ (T-tape 508-12-45; RainFlo Irrigation, East Earl, PA)] were applied to mulched beds. Pest control included one application after transplanting of imidacloprid (Bayer Crop Science, KS City, MO) through the drip irrigation for striped cucumber beetle (Acalymma vittatum), and an application of chlorothalonil (ISK Biotech Corp., Mentor, OH), myclobutanil (Kingtai Chemicals, Binijang, China) and triflumizole (Uniroyal Chemical Co., Bethany, CT) at KRF and WRF on 26 Aug. for suppressing a severe infection of downy mildew (Pseudoperonospora cubensis). Weed control was performed by mechanical and manual cultivation between raised beds as needed.

Grafting, TRANSPLANTING, AND DATA COLlection, 2015. Melon seeds for grafting were sown on 6 May for the WRF planting and on 18 May for the KRF planting in 50-cell plug trays containing soilless medium (Pro-Mix BX; Premier Tech, Quakertown, PA). Two days after melon seeding, seeds of rootstock cultivars were scarified by nicking seeds at the cotyledon end with a scalpel and sown in 38-cell plug trays. NG 'Halona' melon plants were sown at the same time as the rootstocks to compensate for the delay in grafted seedlings from the grafting process. A growth chamber (PGRl5; Conviron, Winnipeg, Canada) was used for seed germination and healing of GR plants. Growth chamber settings were day/ night temperatures of $25 / 22{ }^{\circ} \mathrm{C}$ for $12 \mathrm{~h}$ each, a 16-h photoperiod with florescent lighting at $\approx 250$ $\mu \mathrm{mol} \cdot \mathrm{m}^{-2} \cdot \mathrm{s}^{-1}$ photosynthetic photon flux $(P P F)$, and $\approx 95 \%$ relative humidity $(\mathrm{RH})$.

Melon plants were grafted on 15 and 27 May respectively, for the WRF and KRF planting, when both rootstock and scion seedlings exhibited 
emergence of the first true leaf. The one cotyledon grafting (OCG) method was used (Kubota et al., 2008). The OCG was made by removing one rootstock cotyledon and both the apical and lateral meristems with a razor blade. $\mathrm{A} \approx 45^{\circ}$ cut, 0.25 inch long, was made from the point of cotyledon insertion toward the base of the hypocotyl. The hypocotyl of the scion was cut at $a \approx 45^{\circ}, 0.75$ inch below the cotyledons, and cut sides of both rootstock and scion were joined and held together by a $6-\mathrm{mm}$ spring-loaded plastic grafting clip (Yiwu Bingfeng Trading Co., Yiwu, China).

The GR seedlings were placed into the growth chamber and plastic domes measuring $11.5 \times 21.5 \times 7.5$ inches (width $\times$ length $\times$ height) were placed over the plants to ensure $\approx 95 \%$ RH. The plastic domes were blackened with paint to block light, as the growth chamber was also used to grow the NG seedlings. Three days after grafting (DAG) the plastic dome lids were removed for $2 \mathrm{~h}$ to begin acclimation of the seedlings. At 4 DAG, plants were moved to a greenhouse set at $25 / 18{ }^{\circ} \mathrm{C}$ day/night with natural sunlight. Clear domed lids were placed over seedlings with vents open for slow acclimatization to the greenhouse $\mathrm{RH}(\approx 65 \%)$. Six DAG the clear lids were removed for $2 \mathrm{~h}$ to acclimate the seedlings to the ambient RH. Seven DAG, the domes were removed permanently, the remaining rootstock cotyledons were removed to improve air movement within the canopy, and plants were watered with 150 ppm $15 \mathrm{~N}-1.7 \mathrm{P}-$ $12.5 \mathrm{~K}$ fertilizer solution. At this time, plants were moved to another greenhouse with a similar temperature regime, under natural sunlight, until transfer to the field for transplanting.

The experimental design at both sites was a randomized complete block with three replicates (blocks) of three treatments. Treatments were NG, 'Halona' melon grafted to 'Carnivor' (GR/'Carnivor'), and 'Halona' melon grafted to 'NH1320' (GR/'NH1320'). Transplants at the four-leaf stage were field-planted on 3 June at WRF and 10 June at KRF, with a plant spacing of $2 \mathrm{ft}$ within row and $8 \mathrm{ft}$ between rows with either 10 (WRF) or 8 (KRF) plants per replicated treatment plot. The difference in plant numbers between WRF and
KRF is due to a malfunctioning growth chamber during healing, affecting the number of healthy GR transplants. Research plots were bounded by rows of melon plants comprising mixed melon breeding lines. Plants were irrigated as needed based on general guidelines for drip irrigation systems (Clark and Smajstrla, 1996), crop water coefficients $\left(k_{c}\right)$ for melon between 0.2 and 0.85 (Allen et al., 1998), and reference evapotranspiration $\left(\mathrm{ET}_{0}\right)$ values (Eagleman, 1967) calculated from data on temperature, humidity, rain, and solar radiation from the UNH Weather Station located in Durham. Irrigation usually consisted of $2 \mathrm{~h}$ irrigations twice per week once vines began to run out into the row and during periods of full sun. Beginning 1 week before harvest, when NG plants began to show some wilting of foliage, plants were irrigated for 2 $h$, three times per week until end of the peak harvest. Vines were trained periodically to maintain clear walking lanes between beds.

Data on leaf and lateral branch numbers of five randomly selected plants per plot were recorded on 2 July for both WRF and KRF study sites. Data were recorded for date of first fruit set in each plot. Melons were harvested three times per week at forced full slip. At each harvest, melons weighing less than $800 \mathrm{~g}$ and fruit that were either misshapen, had marginal netting, or severe cracking were categorized as unmarketable, were counted, weighed, and then discarded. The total number and weight of marketable fruit were recorded, and soluble solids content (SSC) were measured for every fruit. The SSC was measured using a handheld refractometer (RHB-32; Westover Scientific, Bothell, WA) with two samples per melon at a flesh depth of $\approx 0.5$ inch from the center at the equatorial region of fruit.

2016 SEASON EXTENSION STUDY. The experimental field, located at $\mathrm{KRF}$, consisted of eight rows $\approx 980$ $\mathrm{ft}$ long, with the outside rows as guard rows planted to hybrid melons, and drip lines running the length of the field. Similar drip tape as in 2015 was installed but 1.5 -mil embossed, black plastic mulch was used instead of the biodegradable mulch (Rain-Flo Irrigation). The experiment design was a split plot with a nested main plot and four replicate blocks. The main plot was irrigation, and the randomized subplots were grafting treatment: NG and GR; and three planting dates: 12 and 21 May and 1 June. The four blocks were arranged longitudinally from top to bottom of the field, with $10 \mathrm{ft}$ between blocks. Each treatment plot consisted of eight plants. The irrigation treatments were randomly assigned to the rows with three rows irrigated for $2 \mathrm{~h}$ every $2 \mathrm{~d}$ (2-d Irr) or three rows at a lower frequency in which plants were irrigated for 2 h every 4 $\mathrm{d}$ (4-d Irr). Use of these two irrigation regimes were based on several years of experience at KRF, the 2015 grafting results, knowledge of expected $\mathrm{ET}_{0}$ values in our region in July and August, and a peak $\mathrm{k}_{\mathrm{c}}$ of 0.85 for cantaloupe (Allen et al., 1998). As such, we chose the two irrigation levels: The 2-d Irr, expected to be more than sufficient under most weather circumstances and degree of leaf canopy cover, and the 4-d Irr, which might not provide sufficient moisture during the period of peak leaf canopy development and heavy fruit load together with unseasonably hot weather. It should be noted that early-maturing cultivars rarely reach full leaf canopy cover and therefore would not reach a peak $k_{c}$ value of 0.85 under northern New England conditions. On the basis of estimated soil available water volume within a raised bed $2 \mathrm{ft}$ wide with fine sandy loam soil (Clark and Smajstrla, 1996), and the rate of discharge from emitters spaced $1 \mathrm{ft}$ apart, we calculated that it would take nearly $5 \mathrm{~h}$ of irrigation to replenish every 1 inch of water loss through evapotranspiration.

The three planting dates were chosen to represent extremely early, early, and recommended planting dates for melon production in southern New Hampshire. This was based on an evaluation of May temperature data recorded at the UNH weather station, during the previous 15 years. The earliest approximate planting date was judged to be 12 May to avoid a moderately high probability of a low temperature event that might cause serious injury to seedlings, even with protection provided by a wide floating rowcover.

'Halona' melon seeds for grafting scions were sown in 50-cell plug 
trays containing soilless medium. Two days later, seeds of NG melon and rootstock 'NH1320' were sown in 50-cell plug trays. Both melon and rootstock plug trays were placed on a propagation bench with intermittent mist inside a greenhouse with air temperature maintained at $\approx 26{ }^{\circ} \mathrm{C}$. At the two-leaf stage, NG plants were moved to a greenhouse with natural light, ambient $\mathrm{RH}$, and a temperature range between 18 and $24^{\circ} \mathrm{C}$, to await field transplanting. Grafting commenced when both melon and rootstock seedlings had unfolded first leaves. Plants were grafted using the OCG method together with root excision of the rootstock (Guan and Zhao, 2015). With root excision, the roots were excised 2.5 inches below the grafting clip and GR seedlings restuck in moist soilless medium in 50-cell plug trays. Grafted plants were covered with clear dome lids provided with two adjustable venting dials and placed in healing chamber under low light $\left(\approx 100 \mu \mathrm{mol} \cdot \mathrm{m}^{-2} \cdot \mathrm{s}^{-1} \mathrm{PPF}\right)$, provided by two light emitting diode (LED) light bars [ $48 \times 2$ inches, F6 spectrum (Eclipse ESI series; Illumitex, Houston, TX)]. The healing chamber, constructed on a greenhouse bench in the Macfarlane greenhouse complex (Durham, NH), consisted of one sheet of white polyethylene covered with blackout cloth with a reflective outer covering, and draped over metal pipes placed $3.5 \mathrm{ft}$ apart and $3 \mathrm{ft}$ above the base of the greenhouse bench. Light bars were hung on adjustable cables attached to the frame. The light spectrum for LEDs was $49.5 \%$ blue, $49.9 \%$ red, $0.5 \%$ green, and $0.1 \%$ far-red. At 4 $\mathrm{DAG}$, the PPF was raised to $\approx 250$ $\mu \mathrm{mol} \cdot \mathrm{m}^{-2} \cdot \mathrm{s}^{-1}$ by lowering light bars, and vents on top of clear dome lids were opened to allow air circulation and reduce humidity. At $6 \mathrm{DAG}$, the lids were removed for $2 \mathrm{~h}$ to allow for acclimation of plants to ambient $\mathrm{RH}$ and then replaced. The lids were permanently removed at eight DAG. At $10 \mathrm{DAG}$, we removed rootstock cotyledons and moved plants to the greenhouse alongside NG plants. Two days before transplanting, the plants were moved to an unheated greenhouse at the WRF for hardening off before transplanting.

Plant spacing was $2 \mathrm{ft}$ within-row and $8 \mathrm{ft}$ between-rows. On $12 \mathrm{May}$, a wide $(50 \mathrm{ft})$ floating rowcover $[0.9$ $\mathrm{oz} / \mathrm{yard}^{2}$ nonwoven fabric (AG-30; Agribon, Berry Plastics, Evansville, IN)], was placed over plots for frost protection and secured into place with sandbags. On 21 May, rowcovers were removed to allow for transplanting the second set of plants, and then replaced. On 25 May, ambient air temperatures rose above $28{ }^{\circ} \mathrm{C}$, and floating rowcovers were permanently removed. Cultural methods were similar to those used in Summer 2015 with exception of the irrigation regimens. Beginning on 3 June, the irrigation treatment commenced. Data were recorded on date of anthesis of first pistillate flowers per plot, individual fruit size (kilograms), SSC of fruit, fruit numbers, total fruit weight (kilograms), and numbers and weight of unmarketable fruit.

Soil moisture and temperature at $6 \mathrm{~cm}$ below the mulch surface, and shaded air temperature at $10 \mathrm{~cm}$ above the mulch surface were recorded with four data loggers (Tomst, Prague, Czech Republic). Four sensors were randomly placed into field plots on 19 May and four more on 8 June 2016 with two sensors represented within each block, and at least one sensor within each irrigation row. Measurements were taken at 15-min intervals. Air temperature before 19 May was imputed using temperature data from the UNH weather station and the average temperature recorded by the sensors under the rowcover. Statistical analysis was performed using JMP Pro (version 13; SAS Institute, Cary, NC). Two-way analysis of variance was used where applicable with a $P \leq$ 0.05 level of significance, and Tukey's honestly significant difference multiple comparison test to determine differences among treatment means.

\section{Results}

EARly PLANT DEVELOPMENT, 2015. At 4 weeks after transplanting at the WRF and 3 weeks after transplanting at the KRF, there were no significant differences in leaf numbers and lateral branching between NG plants and those grafted to rootstocks 'NH1320' and 'Carnivor' (Table 1). However, leaf and lateral numbers were highly variable among plants within treatment plots for both NG and GR plants. Within 5 to 6 weeks after transplanting, vine length and the leaf canopies of GR plants were observed to be more extensive than in NG plants for all plots. At both WRF and KRF sites, this growth differential became more pronounced as the season progressed; as fruit reached maturity, leaf canopies of NG but not GR plants showed wilting during sunny days (Fig. 1).

Fruit Yield and Quality, 2015. The mean number of marketable melons harvested per plot was not significantly different among treatments at either research site ( $\mathrm{Ta}-$ ble 2). Fruit size among the GR treatments was not significantly different, but fruit size was significantly higher in GR than NG treatments, with the size increases among GR treatments greater at $\mathrm{KRF}(45 \%$ to $71 \%)$ than at WRF $(22 \%$ to $33 \%)$ (Table 2). The number of unmarketable fruit was low and not significantly different among treatments. At the WRF, total marketable yield (megagrams per hectare) of GR/'NH1320' and GR/'Carnivor' treatments were $44 \%$ and $57 \%$ higher, respectively, than for NG plants (Fig. 2). At the KRF, total marketable yield of GR/ 'NH1320' plants and GR/'Carnivor' were $90 \%$ and $100 \%$ higher, respectively, than for the NG treatment. The high total marketable yield of GR/'Carnivor' was obtained despite several missing plants per plot. Two plots of the GR/'Carnivor' had missing plants at KRF due to high winds within the first 2 weeks of transplantation, which caused breakage below the graft and replacement plants were not available.

The SSC of melon fruit was used as the parameter to judge eating quality. For all treatments at WRF and KRF sites, the mean SSC was $11 \%$ or higher in melons harvested before 22 and 25 Aug., respectively (Table 2), before severe foliage loss to downy mildew reduced mean SSC below $10 \%$ (data not shown). The mean SSCs for NG melons at WRF were significantly higher than those of GR/'NH1320', but not those of GR/'Carnivor' (Table 2). There was no difference in the mean SSC among treatments at KRF (Table 2).

SeAson EXtension, 2015. The first marketable fruit from the WRF were harvested from NG plants on 29 July and 4 and 7 Aug. 2015, respectively for the GR/'NH1320' and $\mathrm{GR} /$ 'Carnivor' rootstock treatments 
(data not shown). However, the early harvests from NG and GR treatments consisted of single fruit, and first harvests of moderately large numbers of fruit were $6 \mathrm{Aug}$. for the NG treatment and 12 Aug. for both GR treatments (Fig. 3A). Although melon harvests from GR plants were delayed compared with NG plants, per-harvest total marketable weight (kilograms) of GR plants steadily increased overtime until 24 Aug., whereas per-harvest total marketable weight (kilograms) of NG plants peaked on 12 Aug. and then decreased appreciably. For NG plants, $71 \%$ of marketable fruit were harvested by 18 Aug., whereas the largest portion of marketable fruit $79 \%$ to $80 \%$ ) for GR/'NHI320' and GR/ 'Carnivor' treatments were harvested between 17 and 26 Aug.

Table 1. Mean and SD of number of unfurled leaves and laterals per plant in nongrafted (NG) 'Halona' melon, 'Halona' melon grafted to 'NH1320' (GR/ 'NH1320'), and 'Carnivor' (GR/'Carnivor') interspecific hybrid squash rootstocks 29 and $22 \mathrm{~d}$ after planting, respectively, at Woodman (WRF) and Kingman (KRF) Research Farms located in Durham and Madbury, NH, respectively.

\begin{tabular}{|c|c|c|c|c|}
\hline \multirow[b]{2}{*}{ Treatment } & \multicolumn{2}{|c|}{ WRF } & \multicolumn{2}{|c|}{ KRF } \\
\hline & Leaves & Laterals & Leaves & Laterals \\
\hline & \multicolumn{4}{|c|}{$[\text { mean } \pm \text { SD }(\text { no. })]^{\mathrm{z}}$} \\
\hline NG & $25.9 \pm 3.2$ & $3.1 \pm 0.1$ & $16.7 \pm 3.7$ & $3.1 \pm 0.1$ \\
\hline GR/NH1320 & $25.5 \pm 3.2$ & $3.4 \pm 0.6$ & $18.0 \pm 1.2$ & $3.4 \pm 0.6$ \\
\hline GR/Carnivor & $24.2 \pm 3.2$ & $3.1 \pm 0.8$ & $14.4 \pm 1.7$ & $3.1 \pm 0.8$ \\
\hline
\end{tabular}

${ }^{\mathrm{z}}$ Mean from five random plants in each of three replicate plots per treatment. Differences not significant at $P \leq 0.05$.
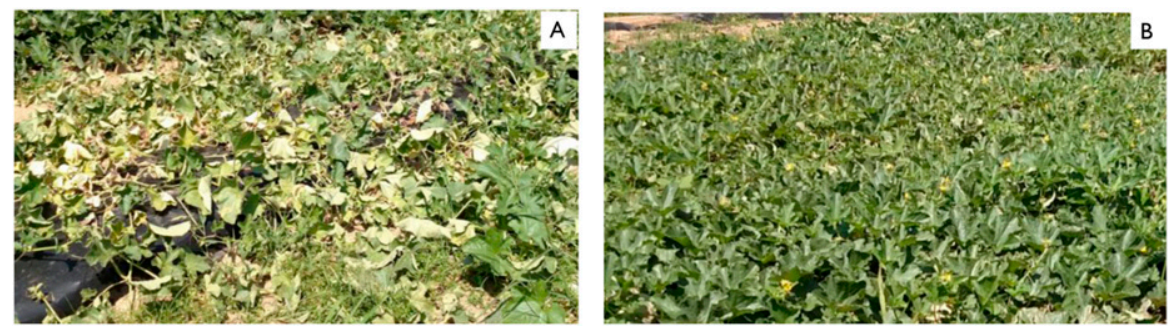

Fig. 1. Leaf canopy images of (A) nongrafted 'Halona' melon showing signs of wilting and (B) 'Halona' melon grafted to an interspecific hybrid squash rootstock showing lack of wilting. Images taken on the first day of harvest for study located at the Kingman Research Farm in Madbury, NH, on 10 Aug. 2015.

The KRF plots were transplanted on 10 June, $7 \mathrm{~d}$ later than plots at the WRF. The first marketable melons from the NG plants were harvested on 10 Aug. (Fig. 3), 12 d later than in the WRF plots. The NG plants reached peak production on 17 Aug. and declined until the end of the season (Fig. 3B). Melons from GR/ 'NHl320' and GR/'Carnivor' treatments were first harvested, respectively, on 12 and 13 Aug. Total marketable weight (kilograms) per harvest remained relatively high in GR/'NHl320' and GR/'Carnivor' treatments until the end of the harvest season. NG plants produced $88 \%$ of total marketable weight (kilograms) between 12 and 20 Aug., whereas $90 \%$ to $91 \%$ of marketable fruit in GR/'NH1320' and GR/'Carnivor' treatments were harvested between 17 and 26 Aug. (Fig. 3B). Harvests were ended on 28 Aug. because downy mildew caused severe leaf necrosis, arresting fruit growth and development at both the WRF and KRF locations.

Temperature and EARLY PLANT DEVELOPMENT IN 2016. As a result of using rowcovers from 12 to 25 May, the average maximum air temperatures for the first 3 weeks of growth for each planting date were higher for the 12 May transplants $\left(31.5^{\circ} \mathrm{C}\right)$ than for the 21 May $\left(28.9^{\circ} \mathrm{C}\right)$, and 1 June $\left(27.9^{\circ} \mathrm{C}\right)$ transplants (Fig. 4). The average minimum air temperatures during the initial 3 weeks of growth were $10.2,12.2$, and $11.4{ }^{\circ} \mathrm{C}$, respectively, for 12 and 21 May, and 1 June planting dates. During the

Table 2. Mean marketable and unmarketable fruit weight and fruit numbers and marketable fruit soluble solids content (SSC) among nongrafted 'Halona' melon (NG) and 'Halona' melon grafted to either 'NH1320' (GR/'NH1320') or 'Carnivor' interspecific hybrid squash rootstocks (GR/'Carnivor') at the Woodman and Kingman Research Farms located in Durham and Madbury, NH, respectively, in 2015.

\begin{tabular}{|c|c|c|c|c|c|c|}
\hline \multirow[b]{2}{*}{ Treatment } & \multirow[b]{2}{*}{ Plants (no./plot) ${ }^{\mathrm{z}}$} & \multicolumn{3}{|c|}{ Marketable fruit } & \multicolumn{2}{|c|}{ Unmarketable fruit } \\
\hline & & $\overline{\text { Fruit wt }(\mathrm{kg})^{\mathrm{y}}}$ & Fruit (no./plot) ${ }^{\mathrm{z}}$ & SSC $(\%)^{x}$ & Fruit wt (kg) & Fruit (no./plot) \\
\hline & \multicolumn{6}{|c|}{ Woodman } \\
\hline GR/'NHI320’ & 9.0 & $1.93 \mathrm{a}$ & $36.0 \mathrm{a}$ & $11.0 \mathrm{~b}$ & $5.10 \mathrm{a}$ & $4.0 \mathrm{a}$ \\
\hline GR/'Carnivor' & 9.7 & $2.02 \mathrm{a}$ & $\begin{array}{l}38.3 \mathrm{a} \\
\quad \text { Kingman }\end{array}$ & $11.5 \mathrm{ab}$ & $1.66 \mathrm{a}$ & $1.7 \mathrm{~b}$ \\
\hline GR/'Carnivor' & 4.7 & $2.45 \mathrm{a}$ & $23.3 \mathrm{a}$ & $11.7 \mathrm{a}$ & $0.46 \mathrm{~b}$ & $0.3 \mathrm{~b}$ \\
\hline
\end{tabular}

${ }^{2}$ Plant spacing was $2 \times 8 \mathrm{ft}(0.6 \times 2.4 \mathrm{~m})$, and the initial plants per plot were 10 plants/plot for Woodman and 8 plants/plot for Kingman.

${ }^{\mathrm{y}} 1 \mathrm{~kg}=2.2046 \mathrm{lb}$.

${ }^{\mathrm{x}}$ SSC from first harvest to 21 or 24 Aug. 2015, respectively, at the Woodman and Kingman Research Farms.

${ }^{\text {w}}$ Mean values for three replicate plots. Different letters within columns indicate significant difference among treatments according to Tukey's honestly significant difference $(P \leq 0.05)$. 


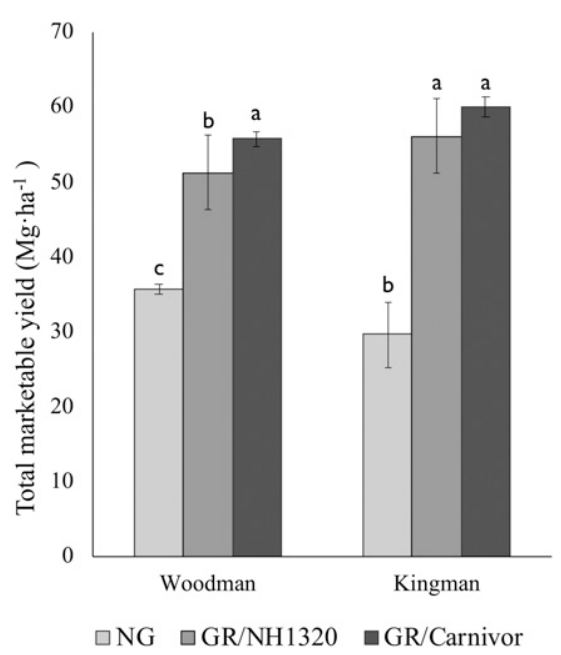

Fig. 2. Comparison of total marketable yield of nongrafted (NG) 'Halona' melon and 'Halona' melon grafted to 'NH1320' (GR/ 'NH1320') and 'Carnivor' (GR/ 'Carnivor') interspecific hybrid squash rootstocks harvested from Woodman and Kingman Research Farms located in Durham and Madbury, NH, respectively. Different letters indicate significant difference within treatment locations according to Tukey's honestly significant difference $(P \leq 0.05)$. Error bars indicate SE; 1 $\mathrm{Mg} \cdot \mathrm{ha}^{-1}=0.4461$ ton/acre.

period from 20 May to 21 June, the minimum soil temperatures at a depth of $6 \mathrm{~cm}$ remained above $17.4^{\circ} \mathrm{C}$ (Fig. 4 ), and the average minimum soil temperatures for the 3 -week periods after transplanting were 19.8 and $19.6{ }^{\circ} \mathrm{C}$, respectively, for the 21 May and 1 June planting dates (Fig. 4). Soil temperatures were not recorded between 12 and 19 May.

There was no visible evidence of CI, such as yellowing of leaves or wilting of seedlings, to either NG or GR plants transplanted on 12 May. Three weeks after transplanting, leaf canopy development and lateral branching of plants from the 12 May planting appeared visibly less extensive in GR (Fig. 5A) than in NG plants (Fig. 5B). There were no significant differences between irrigation treatments for days after transplantation (DAT) to date of first pistillate flower or date of first fruit, nor from first pistillate flower to date of first fruit. In contrast to the less prolific growth and development of GR vs. NG, DAT to first pistillate flowers among the three planting dates were similar (Table 3 ). The anthesis of the

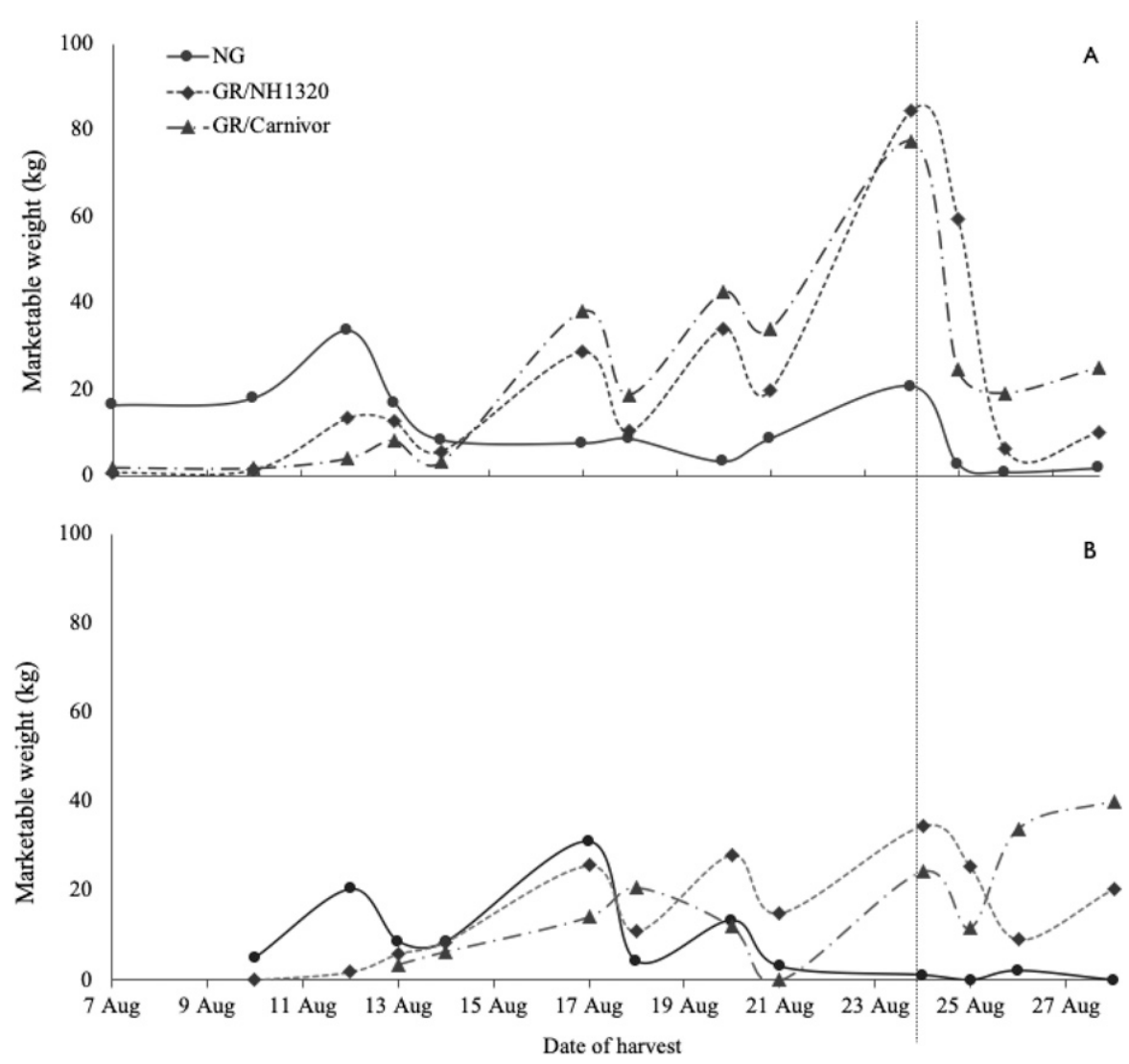

Fig. 3. Scatter plot of total marketable weight of nongrafted (NG) 'Halona' melon and 'Halona' melon grafted to 'NH1320' (GR/'NH1320') and 'Carnivor' (GR/ 'Carnivor') interspecific hybrid squash rootstocks harvested over time at the (A) Woodman and (B) Kingman Research Farms located in Durham and Madbury, $\mathrm{NH}$, respectively. Vertical line indicates the date after which there was a marked drop in fruit growth and soluble solids content of melons due to extensive downy mildew infection; $1 \mathrm{~kg}=2.2046 \mathrm{lb}$.

first pistillate flowers occurred earlier in NG than in GR plants and were 21 and 25 DAT, respectively $(P=$ $0.001)$. A similar trend occurred in DAT to first fruit harvest for all three planting dates and were 63 DAT in NG and 68 DAT in GR plants $(P<$ $0.001)$. However, for both $\mathrm{NG}$ and GR the period from first pistillate flowering to first ripe fruit was shorter for the last planting date $(39 \mathrm{~d})$ compared with the 12 and 21 May planting dates which were 46 and 42 d, respectively $(P<0.001)$.

In contrast to the more prolific early growth and development in $\mathrm{NG}$ vs. GR plants at $21 \mathrm{DAT}$, vine growth and leaf canopy development were visually more extensive in GR (Fig. 5C) than in NG plants (Fig. 5D) at 35 DAT. This growth differential between NG and GR plants became more accentuated as the season progressed, and as fruit began reaching maturity, GR vines filled in between rows, whereas growth of NG plants slowed or ceased, and plants showed periodic wilting during periods of hot, sunny weather (Fig. 6).

FRUIT YIELD AND QUALITY IN 2016. Regardless of planting date and irrigation frequency, GR plants produced significantly higher total marketable yield than NG plants ( $\mathrm{Ta}-$ ble 4 ). The total marketable yield of GR for planting dates 12 and 21 May, and 1 June were, respectively, 130.1, 121.8, and $120.0 \mathrm{Mg} \cdot \mathrm{ha}^{-1}$, were higher than $62.4,57.4$, and 56.4 $\mathrm{Mg} \cdot \mathrm{ha}^{-1}$, respectively, for NG plants. Total marketable yield of GR plants with the 2-d Irr for the 12 and 21 May, and 1 June planting dates were, respectively, 128.7, 113.6, and 124.5 $\mathrm{Mg} \cdot \mathrm{ha}^{-1}$, compared with 55.7, 51.0, and $50.1 \mathrm{Mg} \cdot \mathrm{ha}^{-1}$, respectively, for NG plants. Total marketable yield of GR plants with the 4-d Irr for the 12 and 21 May, and 1 June planting dates were, respectively, 110.5, 107.8, 


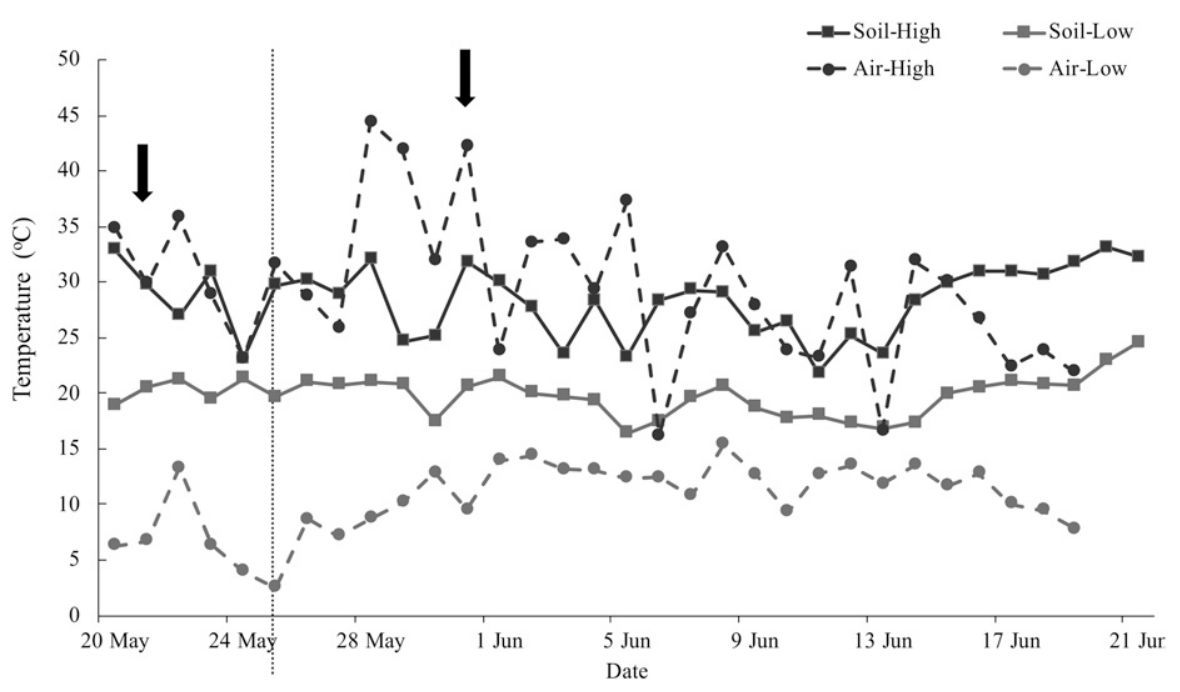

Fig. 4. Maximum and minimum daily temperatures for air at $10 \mathrm{~cm}$ (3.9 inches) above soil line and soil at $10 \mathrm{~cm}$ depth recorded from sensors randomly placed on 19 May 2016. Temperature taken from sensors placed in experimental plots of grafted and nongrafted 'Halona' melon plants planted on 12 and 21 May and 1 June. Vertical line indicates rowcover removal, arrows indicate second and third planting dates; $\left(1.8 \times{ }^{\circ} \mathrm{C}\right)+32={ }^{\circ} \mathrm{F}$.

and $93.4 \mathrm{Mg} \cdot \mathrm{ha}^{-1}$, compared with $57.4,53.8$, and $52.0 \mathrm{Mg} \cdot \mathrm{ha}^{-1}$, respectively, for NG plants. The yield was higher in the GR treatment receiving the $2 \mathrm{~d}$ Irr treatment (Fig. 7). Grafted plants produced both more and larger fruit than NG plants, and these differences were consistent across all three planting dates (Table 4). The relative increase in fruit number in GR compared with NG treatments declined progressively from a $59 \%$ increase for the 12 May planting, to $47 \%$ for the 21 May planting and 33\% for the 1 June planting. On the other hand, the differences in fruit size between NG and GR treatments for the different planting dates was reversed with the smallest increase in fruit size for GR plants occurring in the 12 May transplants (32\%), increasing to $45 \%$ for the 21 May planting and then $56 \%$ for 1 June planting (Fig. 8).

The SSC of melons was similar for GR and NG plants across all planting dates $(P=0.12)$. In most instances mean SSC was $11 \%$ or greater, and for all treatment combinations, at least $75 \%$ of melons had SSC over $10 \%$ (Table 5). Among all treatment combinations, the lowest mean SSC values for each harvest period occurred during peak harvests, 5 to 11 Aug., and then SSC content increased gradually to the first week in September across all treatments (data not shown; see Martin, 2017). As a result, there were moderately strong negative correlations of -0.64 and -0.68 , respectively, between SSC and plot yields per harvest across the first and second planting dates, and a stronger negative correlation $\left(r^{2}=\right.$ -0.81 ) between plot yield and SSC for the last planting date.

SeAson eXtension. First melon harvests from NG plots were 15 and 20 July and 1 Aug., respectively, for the 12 and 21 May and 1 June planting dates, combining data from the two irrigation treatments (Fig. 9A-C). Compared with the NG treatment, first harvests of GR plots were delayed by 2 to $5 \mathrm{~d}$, occurring on 20 July and 25 and 3 Aug., respectively, for the 12 and 21 May and 1 June planting dates. Despite the differences in first ripe fruit among planting dates, the peak yield for all treatments was 8 Aug., and a large proportion of total fruit harvested for all treatments occurred between 5 and 13 Aug. (Fig. 9A-C). There were, nonetheless, distinct differences in patterns of yield over time for NG vs. GR treatments and by planting date. For the early planting date, a substantial amount of fruit $(31 \%$ to $15 \%)$ of the total marketable weight were harvested from both NG and GR treatments before the peak harvest period of 5 to 13 Aug., but only a small proportion of total fruit harvested occurred after the peak harvest period from either
NG $(7 \%)$ or GR (12\%) plants (Fig. 9A). For the second planting date, harvests were more evenly distributed, with $30 \%$ of total marketable weight of NG plants occurring before the peak-harvest period, and $17 \%$ occurring after the peak-harvest period (Fig. 9B). In the GR treatment, a rather small proportion of fruit $(5 \%)$ were harvested before the peak-harvest period, but $36 \%$ were harvested after the peak-harvest period, with relatively robust harvests occurring until 4 Sept. (Fig. 9B). For the last planting date, only a small proportion of fruit in both NG and GR treatments were harvested before the main harvest period, but compared with the earlier planting dates, the pattern of harvests in GR plants was relatively uniform between 5 Aug. and l Sept., with nearly half of the fruit harvested after 13 Aug.

\section{Discussion}

MELON GROWTH AND OCCURRENCE OF SUDDEN WILT. The growth response of melon to grafting varies considerably, depending on rootstock and melon scion compatibility, air and soil temperatures during the growing season, and on rootstock resistance to particular soilborne pathogens reducing crop performance in a particular agricultural ecosystem (Crinò et al., 2007; Edelstein et al., 2004; Lee et al., 2009; Nisini et al., 2002; Traka-Mavrona et al., 2000). There were no noticeable issues with scion/rootstock compatibility when using 'NH1320' and 'Carnivor' rootstocks. In 2016, we had hoped to compare the response of NG and GR plants to episodes of cool temperatures expected with plantings on 12 and 21 May because extended periods of temperatures below $15{ }^{\circ} \mathrm{C}$ can cause CI in melon (Korkmaz and Dufault, 2001). CI is partly expressed as wilting of plants because of a reduced capacity for water uptake by melon roots due to low root zone temperatures (Raleigh, 1941). Thus, we postulated such episodes would hamper growth of NG plants more than GR plants. A study by Rivero et al. (2003) showed that in Europe grafted melons facilitated an earlier melon crop than was possible with NG melons. However, due to the weather pattern in 2016 and use of floating rowcovers, no visible signs of CI were observed, and growth was 

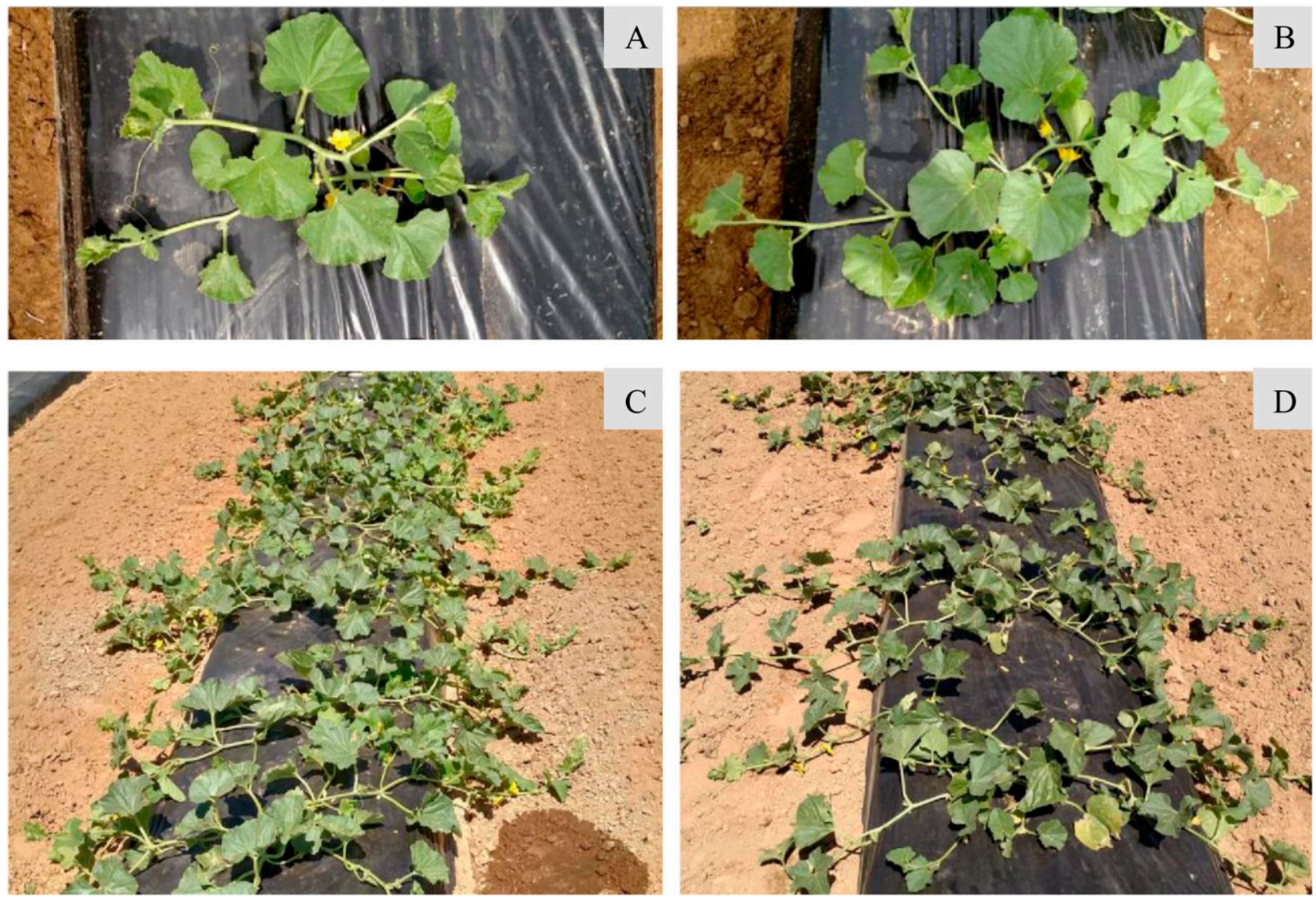

Fig. 5. Comparison of growth of (A) 'Halona' melon grafted to 'NH1320' interspecific hybrid squash rootstock and (B) nongrafted 'Halona' melon plants for the first planting date (12 May 2016) $18 \mathrm{~d}$ after transplanting, and growth of grafted (C) and nongrafted (D) plants at $35 \mathrm{~d}$ after transplanting at Kingman Research Farm in Madbury, NH.

Table 3. Mean and SD for number of days after transplanting to anthesis of first pistillate flowers and to first fruit harvested in 2016, and days from first flowering to first fruit harvest from nongrafted 'Halona' melons (NG) and 'Halona' melon grafted (GR) to 'NH1320' interspecific hybrid rootstock for three planting dates.

\begin{tabular}{|c|c|c|c|}
\hline \multirow[b]{2}{*}{ Treatment } & \multicolumn{2}{|c|}{ Time after transplanting } & \multirow[b]{2}{*}{ Time from flowering to first ripe fruit } \\
\hline & Pistillate flowers $^{\mathrm{z}}$ & First fruit harvested & \\
\hline & \multicolumn{3}{|c|}{$[$ mean \pm SD $(\mathrm{d})]$} \\
\hline NG & $20 \pm 3.7 a^{y}$ & $66 \pm 1.9 \mathrm{bc}$ & $46 \pm 2.7 \mathrm{ab}$ \\
\hline GR & $24 \pm 2.0 \mathrm{a}$ & $71 \pm 1.7 \mathrm{a}$ & $47 \pm 3.4 \mathrm{a}$ \\
\hline \multicolumn{4}{|l|}{21 May } \\
\hline \multicolumn{4}{|l|}{1 June } \\
\hline NG & $22 \pm 2.5 \mathrm{a}$ & $61 \pm 2.9 \mathrm{~d}$ & $39 \pm 4.5 c$ \\
\hline GR & $26 \pm 3.3 \mathrm{a}$ & $64 \pm 1.1 \mathrm{~cd}$ & $40 \pm 4.2 \mathrm{bc}$ \\
\hline
\end{tabular}

${ }^{\mathrm{z}}$ Mean values for eight plants per replication and eight replications (combining data from two irrigation frequencies).

${ }^{\mathrm{y}}$ Different letters within columns indicate significant difference among treatments according to Tukey's honestly significant difference $(P \leq 0.05)$.

not retarded. The earlier planting date had little effect on DAT to first pistillate flowering; whereas days to first fruit harvest from first pistillate flowering were shorter for the 1 June planting date, with either NG or GR treatments.
The most notable results from our studies were the remarkably vigorous growth in GR 'Halona' melon plants vs. NG plants observed within 4 to 5 weeks after transplanting in GR vs. NG plants, and the conspicuous absence of sudden wilt in GR plants.
The "sudden wilt syndrome" is usually associated with severe wilting, often accompanied by plant senescence, and typically results in low SSC in melons. Moreover, many of the newer cultivars grown throughout much of New England have much 

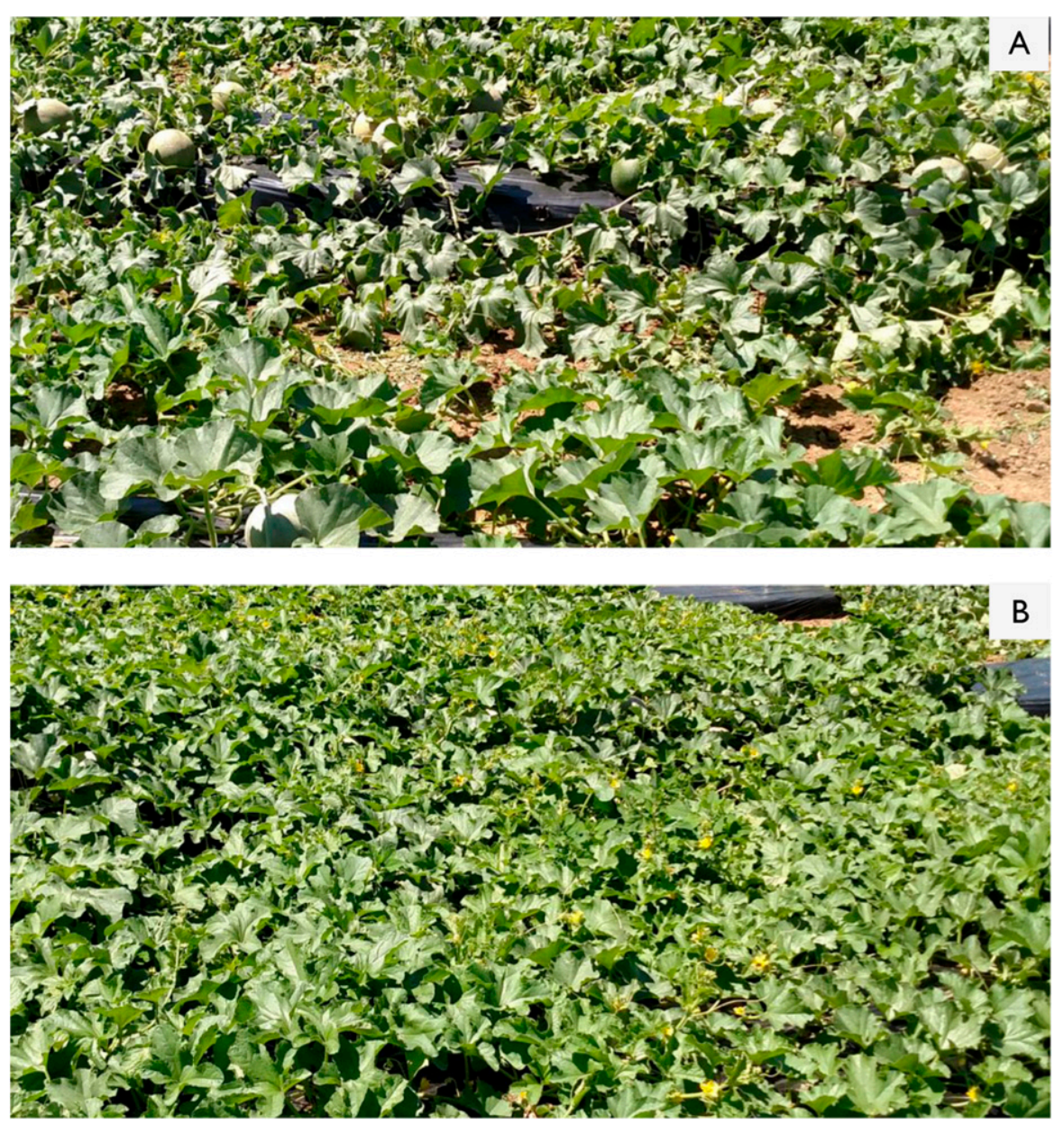

Fig. 6. Appearance of wilting and reduced canopy coverage in (A) nongrafted 'Halona' melon plants compared with the lush growth and vigor of (B) 'Halona' melon grafted to 'NH1320' interspecific hybrid squash rootstock on 4 Aug. 2016, near the beginning of the harvest season for grafting study located at Kingman Research Farm in Madbury, NH.

earlier maturity than those grown in more southernly locations (Loy, 2013). Early fruit development in such cultivars can suppress vine growth (Valantin et al., 1999), increasing susceptibility to sudden wilt. 'Halona' displays moderately vigorous growth for an early maturing cultivar, and in present studies, the degree of wilting was less severe than had been observed in previous years. As a result, melons from NG plants had relatively high SSCs in all experiments. We have not isolated a specific pathogen known to contribute to sudden wilt either from melon plants or soils in our research plots. Although Martyn (2007) and Zitter (1995) have listed numerous pathogens implicated in reports of sudden wilt or late collapse syndromes, a particular soilborne pathogen has not been consistently associated with incidences of sudden wilt in the northeastern United States for several decades (Zitter, 1995).

Numerous grafting studies suggest that enhanced growth and fruit development of the scion is controlled by the effect of the rootstock on increasing water and mineral, and perhaps, hormonal translocation (Jifon et al., 2008; Lee, 1994). Melons cultured on black polyethylene have a relatively shallow root system compared with Cucurbita squash (Knavel and Mohr, 1967). Therefore, when melon plants with moderate vine growth are stressed with a heavy fruit load, a shallow root system may not be capable of providing sufficient moisture to maintain adequate vegetative turgor (Fita et al., 2007), whereas the deeper and more expansive root system in interspecific hybrid squash rootstocks provides a greater capacity for absorbing water and nutrients than melon roots (Fita et al., 2008). In our study, the higher yields, larger fruit, and greater vegetative growth of GR compared with NG plants imply that interspecific hybrid rootstocks provided much enhanced water and nutrient availability to melon scions. Moreover, a few studies provide compelling evidence that melons grafted onto interspecific hybrid rootstocks are able to more efficiently use $\mathrm{N}$ than $\mathrm{NG}$ melon (Colla et al., 2010; Ruiz and Romero, 1999). However, a study by Edelstein et al. (2016) suggests that GR melons may require a different fertilization regime compared with NG melons. The positive response to grafting in our studies may be less of a reflection of rootstock resistance to a pathogen implicit in sudden wilt, but to a display of vegetative vigor in melon plants anchored by a more extensive and efficient root system. Such vigor in GR melons has been underscored in reviews on grafting (Kumar et al., 2017; Lee and Oda, 2003; Lee et al., 2010) and has led to recommendations in some eastern Asia countries to reduce fertilizer application by $30 \%$ or more for GR plants to account for their increased vigor (Lee and Oda, 2003).

GRAFTING AND FRUIT YIELD. Melon grafting throughout much of the world has been largely restricted to use in protected agriculture such as in greenhouses and high and low tunnels (Colla et al., 2017; Lee, 1994). Melons marketed in North America are almost exclusively fieldgrown; therefore, to justify adoption of grafting for field-grown plants, there must be large increases in fruit yields and/or significant increases in eating quality. In a 3-year field study in North and South Carolina, Schultheis et al. (2015) compared NG, self-grafted melon, and melons grafted to the rootstock 'Carnivor', using 15 different melon cultivars representing a wide range of melon types and found no yield advantages to GR melons. Our results demonstrated consistent increases in total marketable weight in GR as compared with NG plants, even with a shortened season in 2015 due to downy mildew and in a much less favorable environment for melon. We have obtained similar yield increases in GR melons at the KRF with several different 
Table 4. Mean marketable yield, marketable and unmarketable individual fruit weight, and fruit number of nongrafted 'Halona' melon (NG) and 'Halona' melon grafted (GR) to 'NH1320' interspecific hybrid squash rootstock for three planting dates with drip irrigation either every $2 \mathrm{~d}$ (2-d Irr) or every $4 \mathrm{~d}$ (4-d Irr) irrigation frequencies.

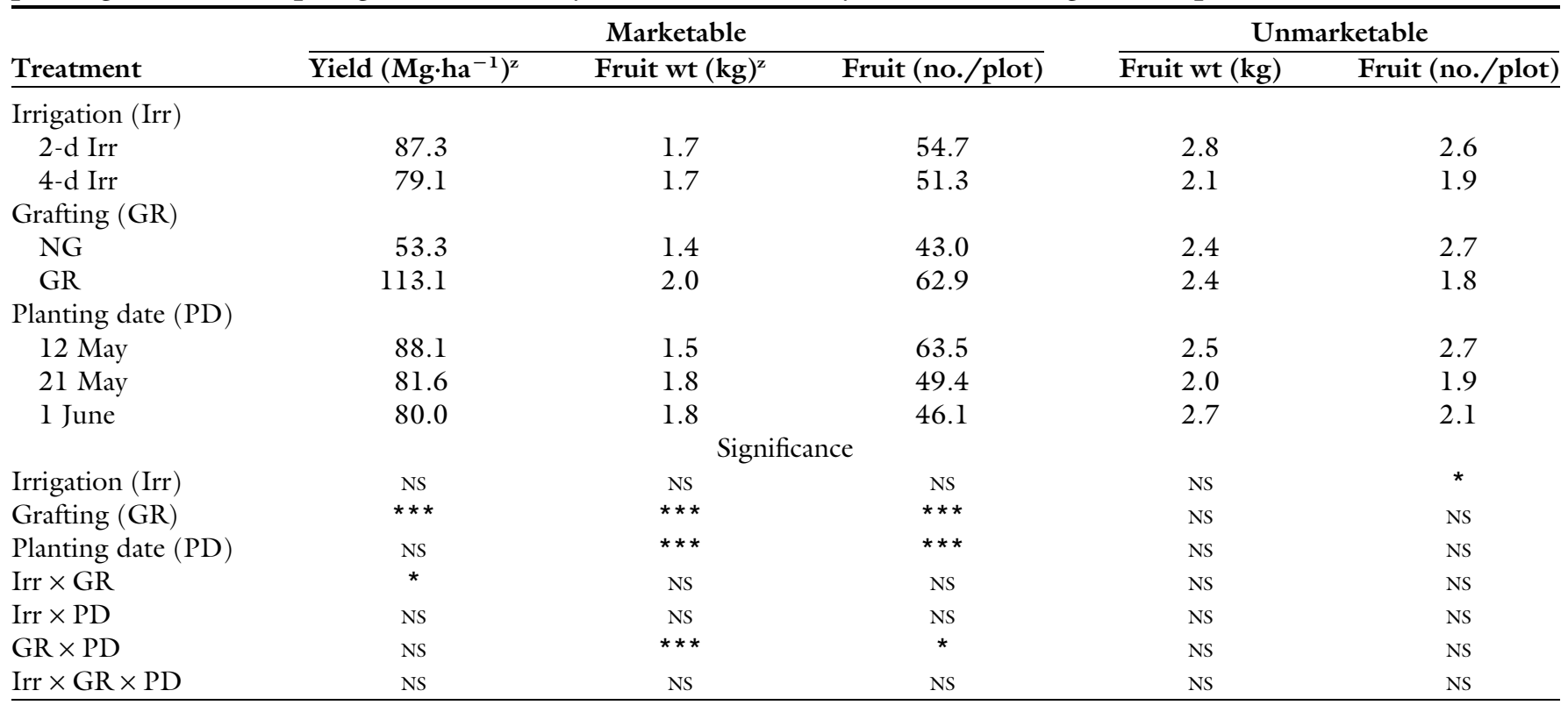

${ }^{\mathrm{z}} \mathrm{l} \mathrm{Mg} \cdot \mathrm{ha}^{-1}=0.446 \mathrm{l}$ ton/acre, $\mathrm{l} \mathrm{kg}=2.2046 \mathrm{lb}$.

Ns, ${ }^{*}, * *, * *$ Nonsignificant or significant at $P \leq 0.05,0.01$, or 0.001 , respectively.

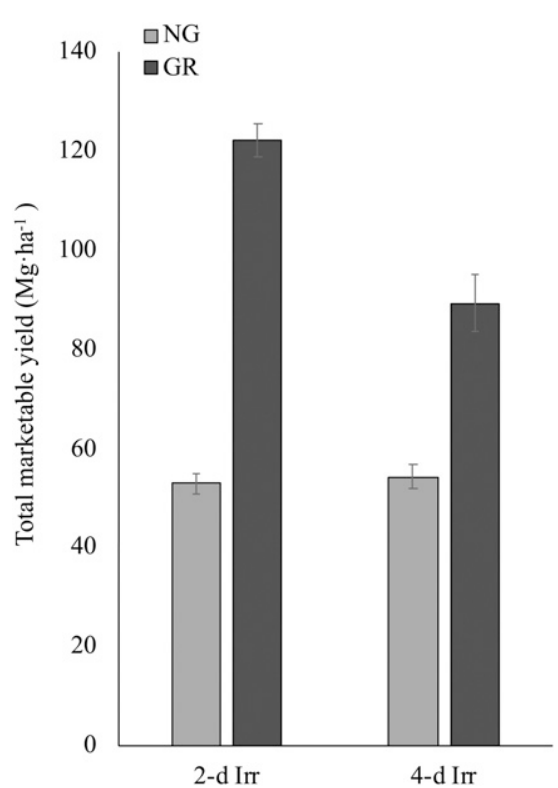

Fig. 7. Comparison of total marketable yield of nongrafted 'Halona' melon (NG) and 'Halona' melon grafted (GR) to 'NH1320' interspecific hybrid squash rootstock as effected by two irrigation frequencies, every $2 \mathrm{~d}$ (2-d Irr) and every $4 \mathrm{~d}$ (4-d Irr). Error bars indicate SE; $1 \mathrm{Mg} \cdot \mathrm{ha}^{-1}=0.4461 \mathrm{ton} /$ acre .

cultivars (J.B. Loy, unpublished results, 2018; Martin, 2017). The yields of marketable fruit on GR plants in 2016 were exceedingly high, ranging from 93.4 to $128.7 \mathrm{Mg} \cdot \mathrm{ha}^{-1}$ across all planting dates and with two irrigation frequencies. Such yields are substantially higher than previously reported melon yields over numerous growing seasons for this region of New England, including yields enhanced with use of rowcovers (Loy, 1991; Loy and Wells, 1975, 1982, 1983). Plant density in the present experiments was slightly lower than in the earlier studies because of wider rows ( $8 \mathrm{ft}$ vs. $6 \mathrm{ft}$ ) and was a lower plant density than generally recommended for New England (Campbell-Nelson et al., 2020). Nonetheless, the range of yields for NG plots in our studies (50.1-57.4 $\mathrm{Mg} \cdot \mathrm{ha}^{-1}$ ) were similar to those in most of the earlier studies cited earlier.

There were seasonal differences in melon response to grafting. $\mathrm{Al}$ though melon yields of GR 'Halona' plants were higher than those of NG plants for all treatment combinations in both years, the higher yields in 2015 were due almost solely to larger fruit size in GR as compared with NG treatments, whereas in 2016, GR treatments produced both greater fruit numbers and larger fruit size than that of NG treatments. Part of this discrepancy can be attributed to a reduction in the harvest season length in 2015 because of severe downy mildew infection. Few fruit remained on NG plants after the last recorded harvest, whereas there were numerous fruit in most plots of GR plants.

IRRIGATION TREATMENTS IN 2016. The constraints of the field setup resulted in different stages of vegetative and reproductive development within irrigation treatment plots throughout much of the growing season, and water regimes could not be tailored to a specific treatment. During the period of peak melon harvests in 2016 (7 to 13 Aug.), we estimated crop water use (ETc) to be $\approx 0.09$ to 0.10 inches, with GR plants at the higher end. On the basis of estimated soil available water volume, soil texture (Clark and Smajstrla, 1996), and the rate of discharge from our drip tape, ample water was supplied to account for water loss through evapotranspiration. There were no visible signs of water deficits in melon plants during the growing season in 2016, with the exception of NG plants displaying some wilting of leaves with either irrigation treatment as fruit reached maturity. Other recent studies have shown GR melon plants to yield higher than NG plants under deficit irrigation conditions (Chen et al., 2016; Ezzo et al., 


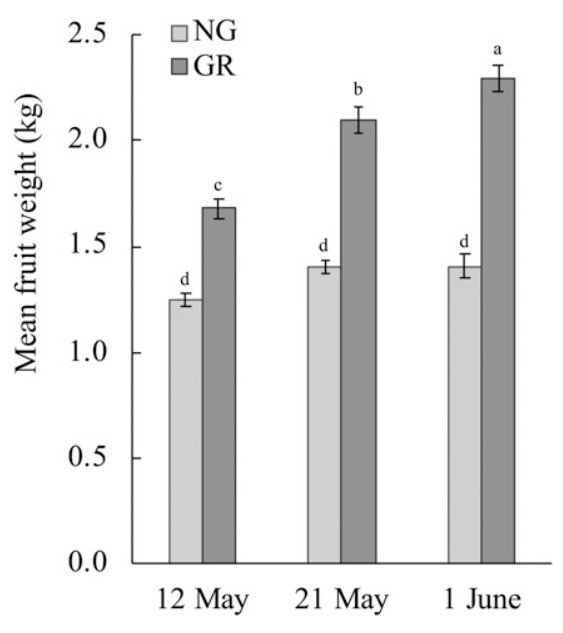

Fig. 8. Mean fruit weight of 'Halona' melon nongrafted (NG) and grafted (GR) to 'NH1320' interspecific hybrid squash rootstock as effected by three planting dates: 12 and 21 May and 1 June 2016. Different letters indicate significant difference across planting dates according to Tukey's honestly significant difference $(P \leq$ 0.05 ). Error bars indicate $S E ; 1 \mathrm{~kg}=$ $2.2046 \mathrm{lb}$.

2020; Sobhi Kivi et al., 2012); demonstrating the benefit of GR melons for drought prone areas and in water conservation.

EXTENDING THE HARVEST SEASON. For local marketing of melons in New England, both early maturity and expansion of the market-window are important considerations. It has been noted previously (Lee, 1994; Lowes et al., 2010) that the harvest season is often extended as a result of increased biotic and abiotic stress resistance from grafted plants, whereas grafting may delay melon maturity (Davis et al., 2008; Guan et al., 2015). Earlier harvests in NG compared with GR plants were consistent in our experiments, with the exception of the last planting date in 2016, and this effect appeared to be related to slower initial vegetative development and later flowering in GR than NG plants. Nonetheless, our results are ambiguous because leaf and lateral branch numbers were not significantly different between GR and NG treatments in 2015.

In 2016, the 12 May planting date did not provide a substantial advantage in early fruit harvest compared with the 21 May planting for either NG or GR treatments, and any such advantage was offset by a shorter harvest window than with later plantings. For 12 May transplants, the first pistillate flowers on NG plants appeared during end of May and in GR plants by 8 June, but no bee activity was observed during this period. The use of beehives to supplement natural bee populations was not an option because of ongoing bee research involving natural populations at the KRF. Therefore, the earliest pistillate flowers likely did not set fruit, contributing to a longer period between first pistillate flowering to first ripe fruit for GR plants in first and second planting dates than the third planting dates. In both high tunnels and in the field, we have observed that GR melon plants can survive cold soil temperatures better than NG plants (J.B. Loy, unpublished results; Martin, 2017). Nonetheless, extremely early planting schedules for GR melons in New England may be an economically risky practice because of potentially adverse problems with fruit set early in the growing season.

The yield increases in GR vs. NG treatments in the present studies were due to both higher peak yields and extended harvest windows, but the distribution of yield across harvest periods varied extensively by year and planting date. In 2015, the major harvest-window for NG plants was 7 to $10 \mathrm{~d}$ but 14 to $17 \mathrm{~d}$ for the GR treatments. Furthermore, the harvest-windows for GR treatments would likely have been longer if not for plants succumbing to downy mildew. In contrast to 2015 , total marketable weight was less evenly distributed across harvest periods in 2016. On the basis of tagging pistillate flowers at anthesis, 'Halona' melons usually reach maturity in 32 to $35 \mathrm{~d}$ from fruit set (J.L. Ohletz and J.B. Loy, unpublished data). Therefore, peak harvests between 5 and 12 Aug. would have required a major period of fruit set across all treatment combinations between $\approx 3$ and 7 July. On the other hand, numerous pistillate flowers appeared within 3 to 4 weeks from transplanting for all planting dates, and maximum temperatures averaged $27{ }^{\circ} \mathrm{C}$ during the last half of June, well above temperatures needed for dehiscence of pollen sacs and fruit set in melon (Mann and Robinson, 1950; Seaton and Kramer, 1939). The similarities in peak harvest for widely distributed transplant dates are probably an anomaly, but we do not have an explanation for this occurrence. For direct retail marketing of melons with a relatively short storage life, stable per-harvest yields are generally advantageous, and thus, for growers in New England, cultivars that not only respond favorably to grafting but also have an extended window of relatively uniform harvests would be desirable.

GRAFTING AND FRUIT QUALITY. SSC of $10 \%$ or greater is generally considered a reasonable criterion for determining acceptable eating quality in melons (Chace et al., 1924; Kader, 1999; Mutton et al., 1981). In some studies, grafting has been reported to adversely affect flesh firmness and texture (Davis et al., 2008; Liu et al., 2017; Schultheis et al., 2015), but we did not examine that trait. However, during pressing of flesh samples for SSC measurements, differences in flesh firmness between melons from NG and GR plants were not readily noticeable. With the exception of slightly higher mean SSC values for 'Halona' melons from NG plants compared with melons grafted to ' $\mathrm{NHl320'}$ ' at the WRF in 2015, differences between $\mathrm{GR}$ and $\mathrm{NG}$ treatments were not significant, and mean SSCs were relatively high, mostly between $11 \%$ and $12 \%$, across all treatment combinations in both 2015 and 2016. Averages can be misleading in evaluating data for consumer acceptability, and perhaps the most important result from our quality evaluations in 2016 was that $75 \%$ to $85 \%$ of melons from GR treatment combinations had SSCs of $10 \%$ or greater. These results are for one melon cultivar, however, and the effect of grafting on SSCs has been shown to vary according to both rootstock and cultivar (Crinò et al., 2007; Kyriacou et al., 2017; Lee et al., 2009; Ruiz et al., 1997; Traka-Mavrona et al., 2000). Although melons with a SSC of $10 \%$ may be acceptable to most consumers, melons with SSC of $11 \%$ or greater are considered "Fancy Grade" or very good (USDA, 2008), and thus, for attracting customers at retail sale outlets, it would be desirable to seek cultivars for future grafting studies that average $12 \%$ or better SSC.

Grafting of melon to interspecific hybrid rootstocks is often 
Table 5. Mean soluble solids content (SSC) and percentage of sampled fruit with $10 \%$ or greater SSC from nongrafted 'Halona' melon (NG) and 'Halona' melon grafted (GR) to 'NH1320' interspecific hybrid squash rootstock at three planting dates and with two irrigation frequencies, every $2 \mathrm{~d}$ (2-d Irr) and every $4 \mathrm{~d}$ (4-d Irr).

\begin{tabular}{|c|c|c|c|c|c|c|}
\hline \multirow[b]{3}{*}{ Treatment } & \multicolumn{6}{|c|}{ Planting date } \\
\hline & \multicolumn{2}{|c|}{12 May } & \multicolumn{2}{|c|}{21 May } & \multicolumn{2}{|c|}{ I June } \\
\hline & $\begin{array}{c}\text { SSC } \\
{[\text { mean } \pm \text { SD }(\%)]^{\mathrm{z}}}\end{array}$ & $\begin{array}{c}\text { SSC } \geq 10 \% \\
{\text { ( } \% \text { fruit })^{y}}^{y}\end{array}$ & $\begin{array}{l}\overline{S S C}[\text { mean } \pm \\
\text { SD }(\%)]\end{array}$ & $\begin{array}{c}\text { SSC } \geq 10 \% \\
\text { (\% fruit) }\end{array}$ & $\begin{array}{l}\overline{S S C}[\text { mean } \pm \\
\text { SD }(\%)]\end{array}$ & $\begin{array}{c}\text { SSC } \geq 10 \% \\
\text { (\% fruit) }\end{array}$ \\
\hline \multicolumn{7}{|l|}{ 2-d Irr } \\
\hline NG & $11.2 \pm 0.5^{\mathrm{z}}$ & 77 & $11.3 \pm 0.5$ & 79 & $11.0 \pm 0.8$ & 75 \\
\hline GR & $11.0 \pm 0.3$ & 77 & $10.7 \pm 0.3$ & 80 & $11.3 \pm 0.8$ & 88 \\
\hline GR & $11.2 \pm 0.4$ & 81 & $11.4 \pm 0.4$ & 85 & $11.2 \pm 0.5$ & 81 \\
\hline
\end{tabular}

${ }^{\mathrm{z}}$ Values represent means of four replications of treatment plots. Treatment differences in SSC for each planting date were not significantly different at $P \leq 0.05$.

${ }^{\mathrm{y}}$ Percentage of fruit sampled with $10 \%$ or greater SSC.

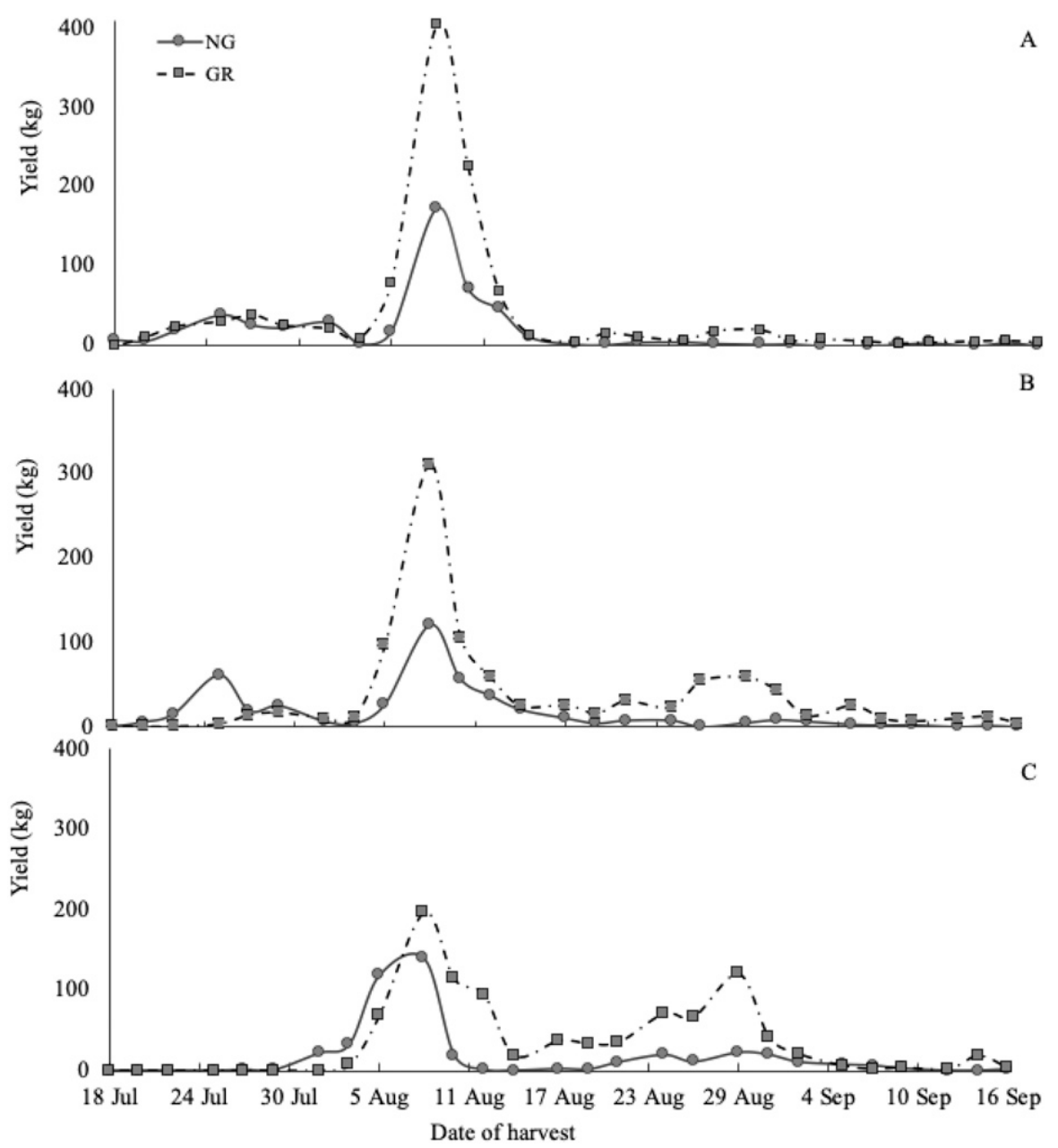

Fig. 9. Comparison of total yield of 'Halona' melon nongrafted (NG) and grafted (GR) to 'NH1320' interspecific hybrid squash rootstock for three planting dates: (A) 12 May, (B) 21 May, and (C) 1 June with irrigation frequencies every 2 or $4 \mathrm{~d}$. Harvest data for two irrigation treatments were combined; $1 \mathrm{~kg}=2.2046 \mathrm{lb}$.

accompanied by increases in fruit size (Colla et al., 2006; Lee et al., 2009; Martin, 2017; Nisini et al., 2002), and such changes may affect consumer demand at retail outlets. In than $2.0 \mathrm{~kg}$, would be priced above $\$ 4.00 /$ melon, and such a high price may negatively impact consumer demand for local melons. The mean size of NG 'Halona' melons in experiments reported here ranged between 1.4 to $1.5 \mathrm{~kg}$; thus, only a small proportion of melons were heavier than $2.0 \mathrm{~kg}$. In contrast, the mean size of GR melons, except for those harvested from the first planting date in 2016 , ranged from 2.0 to $2.4 \mathrm{~kg}$, and as such, a large proportion of these melons would have been in excess of $2.0 \mathrm{~kg}$. Similar increases in size of melons from GR vs. NG plants grown at the KRF has been reported for the cultivars Diplomat, Athena, Goddess, and Sarah's Choice (Martin, 2017). Thus, some of our more recent studies have focused on evaluating smaller-fruited cultivars, such as Sugar Cube, First Kiss, and Sugar Rush, all of which have responded well to grafting.

\section{Conclusions}

Our study found that grafting 'Halona' melons onto interspecific hybrid rootstocks eliminated symptoms of sudden wilt compared with NG melons. Compared with NG plants, GR melon plants displayed enhanced vegetative growth, illustrating the effect of the rootstock root system on promoting uptake of water and nutrients, and likely contributing to the lack of sudden wilt symptoms in the GR plants. Although the first melon harvests of NG plants were 3 to $9 \mathrm{~d}$ earlier than for GR plants, the harvest season was extended in GR plants for most planting dates. Total marketable weight of GR 'Halona' melon plants were $48 \%$ to $155 \%$ higher than those of 
NG plants for several planting dates over two seasons. However, fruit size was substantially larger in GR than in NG treatments, and larger fruit size in large-fruited cultivars may not be desirable for some New England markets; a shift to cultivars with smaller fruit size may be warranted in GR melon.

\section{Literature cited}

Allen, R.G., L.S. Pereira, D. Raes, and M. Smith. 1998. Evapotranspiration-guidelines for computing crop water requirements. FAO Irr. Drain. Paper 56; FAO, Rome, Italy. p. 6541.

Campbell-Nelson, K., K. Ghantous, B. Sideman, C. Smith, and A. Wallingford. 2020. 2020-2021 New England vegetable management guide. Univ. Massachusetts, Amherst.

Chace, E.M., C.G. Church, and F.E. Denny. 1924. Relation between the composition of California cantaloupes and their commercial maturity. U.S. Dept. Agr. Bul. 1250:1-26.

Chen, X., B. Yuan, and Z. Bie. 2016. Effects of deficit irrigation on growth and yield of self-rooted and grafted muskmelon. Trans. Chinese Soc. Eng. 32:133-148.

Clark, G.A. and A.G. Smajstrla. 1996. Design considerations for vegetable crop drip systems. HortTechnology 6:155159.

Cohen, R., C. Horev, Y. Horev, S. Burger, J. Shriber, J. Hershenhorn, J. Katan, and M. Edelstein. 2002. Horticultural and pathological aspects of Fusarium wilt management using grafted melons. HortScience 37:1069-1073.

Colla, G., C.M.C. Suárez, and M. Cardarelli. 2010. Improving nitrogen use efficiency in melon by grafting. HortScience 45:559-565.

Colla, G., F. Pérez-Alfocea, and D. Schwarz. 2017. Vegetable grafting: Principles and practices. CABI, Boston, MA.

Colla, G., Y. Rouphael, M. Cardarelli, D. Massa, A. Salerno, and E. Rea. 2006. Yield, fruit quality and mineral composition of grafted melon plants grown under saline conditions. J. Hort. Sci. Biotechnol. 81:146-152.

Crinò, P., C. Lo Bianco, Y. Rouphael, G. Colla, F. Saccardo, and A. Paratore. 2007. Evaluation of rootstock resistance to fusarium wilt and gummy stem blight and effect on yield and quality of a grafted "inodorus" melon. HortScience 42:521-525.

Davis, A.R., P. Perkins-Veazie, Y. Sakata, S. López-Galarza, J.V. Maroto, S.G. Lee,
Y.C. Huh, Z. Sun, A. Miguel, S.R. King, R. Cohen, and J.M. Lee. 2008. Cucurbit grafting. Crit. Rev. Plant Sci. 27:50-74, doi: $10.1080 / 07352680802053940$.

Eagleman, J.R. 1967. Pan evaporation, and potential and actual evapotranspiration. J. Appl. Meteorol. 6:482-488.

Edelstein, M., Y. Burger, C. Horev, A. Porat, A. Meir, and R. Cohen. 2004. Assessing the effect of genetic and anatomic variation of Cucurbita rootstocks on vigour, survival, and yield of grafted melons. J. Hort. Sci. Biotechnol. 79:370-374.

Edelstein, M., R. Cohen, M. Elkabetz, S. Pivonia, A. Maduel, T. Sadeh-Yarok, and M. Ben-Hur. 2016. The potential of enriched fertilization in overcoming nutritional deficiency in grafted melons. HortScience 51:435-438.

Ezzo, M.I., A.S. Mohamed, A.A. Glala, and S.A. Saleh. 2020. Utilization of grafting technique for sustaining cantaloupe productivity and quality under deficit irrigation water. Bul. Natl. Res. Ctr. 44:1-23, doi: 10.1186/s42269-020-0283-7.

Fita, A., B. Picó, and F. Nuez. 2007. Melon roots under stress: Melon vine decline. Plant Stress 1:93-104.

Fita, A., J. Postma, B. Picó, F. Nuez, J. Lynch, and M. Pitrat. 2008. Root architecture variation in Cucurbita. Cucurbitaceae 2008, Proc. IXth EUCARPIA Genet. Breed. Cucurbitaceae. p. 487-492.

Gaion, L.A., L.T. Braz, and R.F. Carvalho. 2018. Grafting in vegetable crops: A great technique for agriculture. Intl. J. Veg. Sci. 24:85-102, doi: 10.1080/ 19315260.2017 .1357062 .

Guan, W. and X. Zhao. 2015. Effects of grafting methods and root excision on growth characteristics of grafted muskmelon plants. HortTechnology 25:706-713.

Guan, W., X. Zhao, and D.J. Huber. 2015. Grafting with an interspecific hybrid squash rootstock accelerated fruit development and impaired fruit quality of Galia melon. HortScience 50:1833-1836.

Hemphill, D.D. and N.S. Mansour. 1986. Response of muskmelon to three floating rowcovers. J. Amer. Soc. Hort. Sci. 111:513-517.

Jenni, S., D.C. Cloutier, G. Bourgeois, and K.A. Stewart. 1996. A heat unit model to predict growth and development of muskmelon to anthesis of perfect flowers. J. Amer. Soc. Hort. Sci. 121:274-280.

Jifon, J.L., K.M. Crosby, D.I. Leskovar, and M. Miller. 2008. Possible physiological mechanisms for resistance to vine decline diseases in grafted watermelons. Acta Hort. 782:329-334.
Kader, A.A. 1999. Fruit maturity, ripening, and quality measurements. Acta Hort. 485:203-208.

King, S.R., A.R. Davis, X. Zhang, and K. Crosby. 2010. Genetics, breeding and selection of rootstocks for Solanaceae and Cucurbitaceae. Scientia Hort. 127:106111, doi: 10.1016/j.scienta.2010.08.001.

Knavel, D.E. and H.C. Mohr. 1967. Distibution of roots of four different vegetables under paper and polyethylene mulches. Proc. Amer. Soc. Hort. Sci. 91:589-597.

Korkmaz, A. and R.J. Dufault. 2001. Developmental consequences of cold temperature stress at transplanting on seedling and field growth and yield. II. Muskmelon. J. Amer. Soc. Hort. Sci. 126:410-413.

Kubota, C., M.A. McClure, N. KokalisBurelle, M.G. Bausher, and E.N. Rosskopf. 2008. Vegetable grafting: History, use, and current technology status in North America. HortScience 43:16641669.

Kumar, P., Y. Rouphael, M. Cardarelli, and G. Colla. 2017. Vegetable grafting as a tool to improve drought resistance and water use efficiency. Front. Plant Sci. 8:1130, doi: 10.3389/fpls.2017.01130.

Kunkel, K.E. 2016. Expanded analysis of data originally published in: Kunkel, K.E., D.R. Easterling, K. Hubbard, and K. Redmond. 2004. Temporal variations in frost-free season in the United States: 18952000. Geophys. Res. Lett. 31:L03201.

Kyriacou, M.C., Y. Rouphael, G. Colla, R. Zrenner, and D. Schwarz. 2017. Vegetable grafting: The implications of a growing agronomic imperative for vegetable fruit quality and nutritive value. Front. Plant Sci. 8:740, doi: 10.3389/fpls.2017. 00741.

Lee, J.H., J.K. Kwon, K.S. Park, Y.C. Huh, C. Lim, C.D.K. Park, and K.D. Ko. 2009. Effect of different rootstocks on wilting occurrence, plant growth and fruit quality. Korean J. Sci. Technol. 27:211-217.

Lee, J.-M. 1994. Cultivation of grafted vegetables: I. Current status. HortScience 29:235-239.

Lee, J.-M., C. Kubota, S.J. Tsao, Z. Bie, P.H. Echevarria, L. Morra, and M. Oda. 2010. Current status of vegetable grafting: Diffusion, grafting techniques, automation. Scientia Hort. 127:93-105, doi: 10.1016/ j.scienta.2010.08.003.

Lee, J.-M. and M. Oda. 2003. Grafting of herbaceous vegetable and ornamental crops. Hort. Rev. 28:61-124.

Liu, Q., X. Zhao, J.K. Brecht, C.A. Sims, T. Sanchez, and N.S. Dufault. 2017. Fruit 
quality of seedless watermelon grafted to squash rootstocks under different production systems. J. Sci. Food Agr. 97:4704-4711, doi: 10.1002/jsfa.8338.

Lowes, F., C.L. Rivard, and C. Kubota. 2010. Grafting fruiting vegetables to manage soilborne pathogens, foliar pathogens, arthropods and weeds. Scientia Hort. 127:127-146, doi: 10.1016/j.scienta. 2020.09.023.

Loy, J.B. 1991. Solar infrared transmitting, PAR absorbing polyethylene mulch: Physical properties and crop response. Proc. Natl. Agr. Plastics Congr. 23:165-173.

Loy, J.B. 2013. The nuts and bolts of fruit quality in cucurbits. Proc. New England Vege. and Fruit Conf., Manchester, NH. p. 201-204.

Loy, J.B. 2015. Use of interspecific hybrids in squash for fresh market, processing, and grafting rootstocks for melons. Proc. New England Veg. and Fruit Conf., Manchester, NH. p. 157-159.

Loy, J.B. and O.S. Wells. 1975. Response of hybrid muskmelons to polyethylene rowcovers and black polyethylene mulch. Sci. Hort. 3:223-230.

Loy, J.B. and O.S. Wells. 1982. A comparison of slitted polyethylene and spunbonded polyester for plant rowcovers. HortScience 17:405-407.

Loy, J.B. and O.S. Wells. 1983. Use of spunbonded polyester as a plant rowcover over vegetables. Proc. Natl. Agr. Plastics Congr. 17:54-62.

Mann, L.K. and J. Robinson. 1950. Fertilization, seed development, and fruit growth as related to fruit set in the cantaloupe (Cucumis melon L.). Amer. J. Bot. 37:685-687.

Martin, J.L. 2017. Grafting melons increases yield, harvest period, and resistance to sudden wilt. MS Thesis, Univ. New Hampshire, Durham.

Martyn, R.D. 2007. Late-season vine declines of melons: Pathological, cultural or both? Acta Hort. 731:345-356.

Mutton, L.L., B.R. Cullis, and A.B. Blakeney. 1981. The objective definition of eating quality in rockmelon (Cucumis melo L.). J. Sci. Food Agr. 32:385-391.

Nisini, T.P., G. Colla, E. Granati, O. Temperini, P. Crinò, and F. Saccardo. 2002. Rootstock resistance to fusarium wilt and effect on fruit yield and quality of two muskmelon cultivars. Scientia Hort. 93:281-288, doi: 10.1016/S03044238(01)00335-1.
Proietti, S., Y. Rouphael, G. Colla, M. Cardarelli, M. De Agazio, M. Zacchini, E. Rea, S. Moscatello, and A. Battistelli. 2008. Fruit quality of mini-watermelon as affected by grafting and irrigation regimes. J. Sci. Food Agr. 88:1107-1114, doi: $10.1002 /$ jsfa.3207.

Raleigh, G.J. 1941. The effect of culture solution temperature on water intake and wilting of muskmelon. Proc. Amer. Soc. Hort. Sci. 38:487-488.

Rivero, R., J. Ruiz, and L. Romero. 2003. Role of grafting in horticultural plants under stress conditions. J. Food Agr. Environ. 1:70-74.

Rouphael, Y., M.C. Kyriacou, and S.A. Petropoulos. 2018. Improving vegetable quality in controlled environments. Scientia Hort. 234:275-289, doi: 10.1016/ j.Sci.2018.02.033.

Rouphael, Y., D. Schwarz, A. Krumbein, and G. Colla. 2010. Impact of grafting on product quality of fruit vegetables. Scientia Hort. 127:172-179, doi: 10.1016/ j.scienta.2010.09.001.

Ruiz, J., A. Belakbir, I. López-Cantarero, and L. Romero. 1997. Leaf-macronutrient content and yield in grafted melon plants. A model to evaluate the influence of rootstock genotype. Scientia Hort. 71:227-234, doi: 10.1016/S0304-4238(97)00106-4.

Ruiz, J. and L. Romero. 1999. Nitrogen efficiency and metabolism in grafted melon plants. Scientia Hort. 81:113-123, doi: 10.1016/S0176-1617(96)80140-4.

Sakata, Y., T. Ohara, and M. Sugiyama. 2007. The history and present state of the grafting of Cucurbitaceous vegetables in Japan. Acta Hort. 731:159-170.

Schultheis, J., W. Thompson, and R. Hassell. 2015. Specialty melon yield and quality response to grafting in trials conducted in the southeastern United States. Acta Hort. 1086:269-278.

Schwarz, D., Y. Rouphael, G. Colla, and J.H. Venema. 2010. Grafting as a tool to improve tolerance of vegetables to abiotic stresses: Thermal stress, water stress and organic pollutants. Scientia Hort. 127:162-171, doi: 10.1016/j.scienta.2010.09.016.

Seaton, H.L. and J.C. Kramer. 1939. The influence of climatological factors on anthesis and anther dehiscence in the cultivated cucurbits. A preliminary report. Proc. Amer. Soc. Hort. Sci. 36:627-631.

Sobhi Kivi, S., R. Salehi, and A. Liaghat. 2012. Effects of deficit irrigation and grafting on yield and fruit quality of Ira- nian 'Khatooni' melon. Acta Hort. 1038:573-578.

Traka-Mavrona, E., M. Koutsika-Sotiriou, and T. Pritsa. 2000. Response of squash (Cucurbita spp.) as rootstock for melon (Cucumis melo L.). Scientia Hort. 83:353-362, doi: 10.1016/S0304-4238(99) 00088-6.

Uretsky, J. 2012. Development and evaluation of interspecific Cucurbita maxima x Cucurbita moschata hybrids for processing squash. MS Thesis, Univ. New Hamshire, Durham.

U.S. Department of Agriculture. 2008. United States standards for grades of cantaloups. 5 Oct. 2020. <https://www.ams. usda.gov/grades-standards/cantaloupgrades-and-standards $>$.

U.S. Department of Agriculture. 2018. New England vegetable and strawberry report, 2017 crop. 5 Oct. 2020. <https:// www.nass.usda.gov/Statistics_by_State/ New_England_includes /Publications/ Current_News_Release/2018/eos2018_ vegetables.pdf $>$.

Valantin, M., C. Gary, B.E. Vaissiére, and J.S. Frossard. 1999. Effect of fruit load on partitioning of dry matter and energy in cantaloupe (Cucumis melo L.). Ann. Bot. 84:173-181.

Vescera, M. and R.N. Brown. 2016. Effects of three production systems on muskmelon yield quality in New England. HortScience 51:510-517.

Wang, H., Y. Xie, L. Yang, W. Yan, and Z. He. 2019. Study on cold tolerance of different rootstocks of melon seedlings. IOP Conf. Ser. Earth Environ. Sci. $310(5)$.

Waterer, D.R. 1993. Influence of planting date and row covers on yield and economic value muskmelon. Can. J. Plant Sci. 73:281-288.

Wells, O.S. and J.B. Loy. 1985. Intensive vegetable production with row covers. HortScience 20:822-826.

Wells, O.S., J.B. Loy, and T. Natti. 1977. Use of slit mulch for row covers. Proc. Intl. Plastics Congr. 7:448-452.

Wien, H.C. and T.A. Zitter. 2006. Initiating sudden wilt disorder in muskmelon with low-light stress, p. 60-64. In: G.J. Holmes (ed.). Proceedings Cucurbitaceae 2006. Universal Press, Raleigh, NC.

Zitter, T.A. 1995. Sudden wilt of melons from a northeastern U.S. perspective, p. 44-47. In: G. Lester and J. Dunlap (eds.). Proceedings Cucurbitaceae 1994, Gateway Printing, Edinburgh, TX. 